Article

\title{
Zircon U-Pb Geochronology, Geochemistry and Geological Significance of the Anisian Alkaline Basalts in Gejiu District, Yunnan Province
}

\author{
Zhi Shang and Yongqing Chen * \\ School of Earth Sciences and Resources, China University of Geosciences, Beijing 100083, China; \\ shangzhi6609@163.com \\ * Correspondence: yqchen@cugb.edu.cn
}

Received: 6 September 2020; Accepted: 16 November 2020; Published: 18 November 2020

\begin{abstract}
The Gejiu Anisian alkaline basalts (GAAB), distributed in the southern part of the Emeishan large igneous province (ELIP), are crucial to understand the tectonomagmatic activity during the Triassic. Geochronological, geochemical, and $\mathrm{Sr}-\mathrm{Nd}-\mathrm{Pb}$ isotopic analyses were systematically applied to explore the origin, petrogenesis, and tectonic setting of the GAAB, and how they relate to the ELIP. Zircon U-Pb dating set the eruption date at $244 \mathrm{Ma}$. Most of the samples belonged to alkaline basalts and had high $\mathrm{TiO}_{2}$ (2.14-3.23 wt.\%) and $\mathrm{MgO}$ (4.43-19.58 wt.\%) contents. Large ion lithophile elements (LILEs) were enriched relative to high field strength elements (HFSEs). The rare earth elements (REEs) and trace element signatures in the normalized diagrams were similar to oceanic island basalts (OIB) and Emeishan high-Ti basalts. These samples had consistent $\mathrm{Sr}-\mathrm{Nd}$ isotope compositions: the initial ${ }^{87} \mathrm{Sr} /{ }^{86} \mathrm{Sr}$ values ranged from 0.7044 to 0.7048 and $\varepsilon \mathrm{Nd}(\mathrm{t})=3.25-4.92$. The $\mathrm{Pb}$ isotopes were more complex, the $\left({ }^{206} \mathrm{~Pb} /{ }^{204} \mathrm{~Pb}\right) \mathrm{t},\left({ }^{207} \mathrm{~Pb} /{ }^{204} \mathrm{~Pb}\right) \mathrm{t},\left({ }^{208} \mathrm{~Pb} / 204 \mathrm{~Pb}\right) \mathrm{t}$ ratios were $17.493-18.197$, 15.530-15.722, and 37.713-38.853, respectively. Our results indicate that the GAAB originated from the deeper enriched mantle with $5 \%$ to $15 \%$ partial melting of garnet lherzolite and a segregation depth of 2 to $4 \mathrm{GPa}(60-120 \mathrm{~km})$. During the formation of the GAAB, clinopyroxene and Ti-Fe oxides were fractionally crystallized with insignificant crustal contamination. The GAAB were formed in a extensional regime that was related to the Gejiu-Napo rift event in the Triassic.
\end{abstract}

Keywords: gejiu basalts; zircon $\mathrm{U}-\mathrm{Pb}$ dating; geochemistry; $\mathrm{Sr}-\mathrm{Nd}-\mathrm{Pb}$ isotope; petrogenesis; tectonic setting

\section{Introduction}

Basaltic magmatism is a fundamental geological process, and of the various kinds of basalts, alkaline basalts are thought to have unique geological implications [1,2]. Massive stretches of basaltic magma are distributed along the western margin of the South China Block in SW China, making up the widely known Emeishan large igneous province (ELIP), which covers an area of over $5 \times 10^{5} \mathrm{~km}^{2}$ in SW China and northern Vietnam (Figure 1a) [3]. The basalts in the ELIP were mainly formed during the Late-Middle Permian (ca. $260 \mathrm{Ma}$ ) and have been identified as related to a mantle plume [4-12]. The Gejiu Anisian alkaline basalts (GAAB), formed later than the ELIP, are important in understanding the tectonic evolution of the western South China Block during post-ELIP tectonomagmatism.

However, the origin and mechanism behind the formation of the GAAB in the southern ELIP remain controversial and poorly understood, and the links between the GAAB and the ELIP have not been well established. Several formation mechanisms have been proposed for the GAAB, these have included an orogenic environment [13], a within-plate extensional environment [14,15], a back-arc rift basin [16-19], and a decompressive melting of the pre-existing Emeishan plume head induced by a rift 
event $[20,21]$. Nevertheless, no study has been able to provide sufficient evidence to confirm the origin or formation mechanism of the GAAB, likely due to unsystematic sampling and research methods.

In this paper, samples were collected from both outcrop and boreholes in Qilinshan and Laochang. Integrated geochronological, geochemical, and isotopic data were obtained to investigate the origin and formation mechanism of the GAAB, along with any links between the Middle Triassic igneous activity in Gejiu and the ELIP. This analytical data from the Gejiu area will contribute to a better understanding of these, as of yet, unsolved issues.

\section{Geologic Background and Petrography}

The Gejiu ore district is located in the South China block, East of the Ailaoshan belt [22] (Figure 1a). The collision of Indochina and South China Block took place during the Early Triassic, forming the widely known Ailaoshan suture zone, accompanied by complex tectonomagmatism [23]. It extends northwest to the Jinshajiang suture zone and southeastern to the Song Ma suture zone (Figure 1a) [24-26]. The Ailaoshan belt is an NW-SE striking fan-shaped area that narrows to the NW and widens to SE (500 km long, and 10 to $50 \mathrm{~km}$ wide) and this belt can be subdivided into Western, Central, and Eastern Ailaoshan zones from west to east [23].

The GAAB are situated in the eastern part of the Ailaoshan suture zone (Figure 1a) $[3,20,21]$. There are numerous faults in the Gejiu ore district (Figure 1b,c). The Gejiu fault as the southern extension of Xiaojiang fault, which has an SN-trending orientation, is the main fault dividing the Gejiu area into two sectors [22]. The secondary faults, which generally trend EW, show the signature of an equidistant distribution in the eastern sector and divide the Gejiu ore district into five main ore segments, namely the Malage, Songshujiao, Gaosong, Laochang, and Kafang from north to south (Figure 1c). The basalts of interest are primarily located in the eastern sector of the Gejiu ore district.
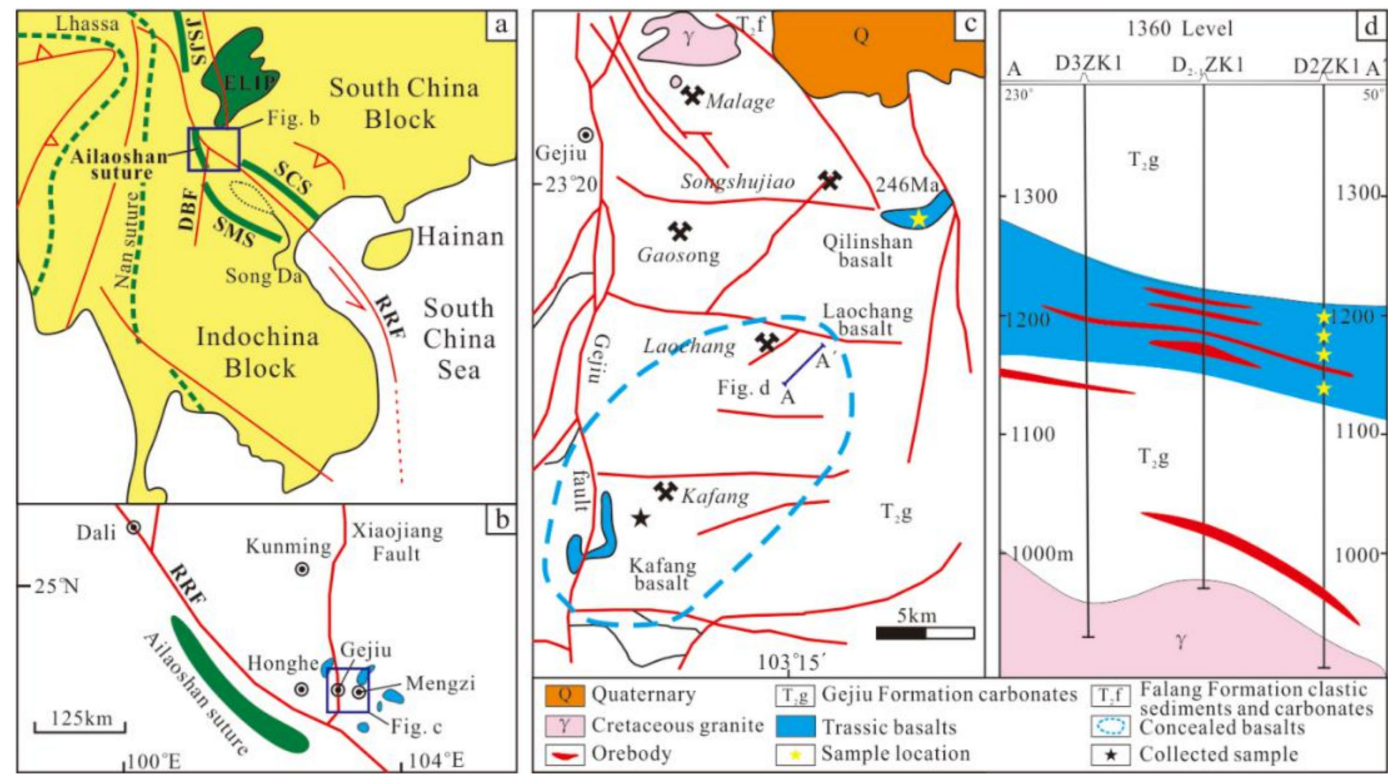

Figure 1. (a) Simplified tectonic map showing the study area in relation to major tectonic units in South China [23], JSJS: Jinshajiang suture, SCS: Song-Chay suture, SMS: Song Ma suture, RRF: Red River fault, DBF: Dien Bien Phu fault; (b) Simplified map showing the location of the study area [27]; (c) Geological map of the Gejiu ore district [21]; (d) Geological section of basalts in Laochang ore segment.

The Triassic GAAB cover an area of nearly $125 \mathrm{~km}^{2}$ in the south of the ELIP, and are widely distributed in the Qilinshan, Laochang, and Kafang ore segments (Figure 1c) [18,20]. The basalts in Laochang and Kafang, which are considered as a unit, are concealed under the ground, while the Qilinshan basalts are exposed at the earth's surface. The Middle Triassic Gejiu Formation carbonates and the Falang Formation fine-grained clastic sediments and carbonates are the dominant strata (over 
$3000 \mathrm{~m}$ ) in the Gejiu ore district. These basaltic lavas are found in the lower part of the Gejiu Formation where they were conformably interbedded within the Gejiu Formation. The Laochang and Kafang basalts exhibit a subhorizontal distribution with an overall dip to the northwest. The thickness of a single layer of the basalt ranges from 0.05 to $30 \mathrm{~m}$, and the total thickness is about $100 \mathrm{~m}[13,21]$. Due to the intrusion of the Mesozoic granitic magmatism, the basalts in Laochang and Kafang have undergone different degrees of metamorphism, forming olivine basalts with weak metamorphism and phlogopite metabasalts that have high degrees of metamorphism [17]. The Qilinshan basalts found in the eastern part of the Songshujiao ore segment underwent relatively low degrees of metamorphism and were less altered than the basalts in Laochang and Kafang.

In this research, outcrop samples were collected from Qilinshan and the borehole samples came from 1360 levels in the Laochang ore segment. Altogether, 59 samples were collected for zircon $\mathrm{U}-\mathrm{Pb}$ dating, geochemical and $\mathrm{Sr}-\mathrm{Nd}-\mathrm{Pb}$ isotope analyses. The sample locations can be seen in Figure 1c,d. These basalts were dark green and had an abundance of amygdaloidal structures (Figure 2a). The oval-shaped amygdales were 0.2 to $2 \mathrm{~cm}$ in diameter and showed directional arrangements. These amygdales exhibited a nonuniform distribution in the basalt samples. Most of the amygdales were filled with silicic material and/or carbonate. Chloritization and actinolitization were common in the basalts. These basalts were mainly composed of pyroxene, plagioclase, olivine (Figure 2b,c), and accessory minerals such as ilmenite and magnetite. The alteration in Laochang basalts was more pervasive and severe than that in Qilinshan basalts, and the alteration minerals were mainly phlogopite, actinolite, chlorite, and tremolite (Figure $2 \mathrm{~d}-\mathrm{f}$ ).
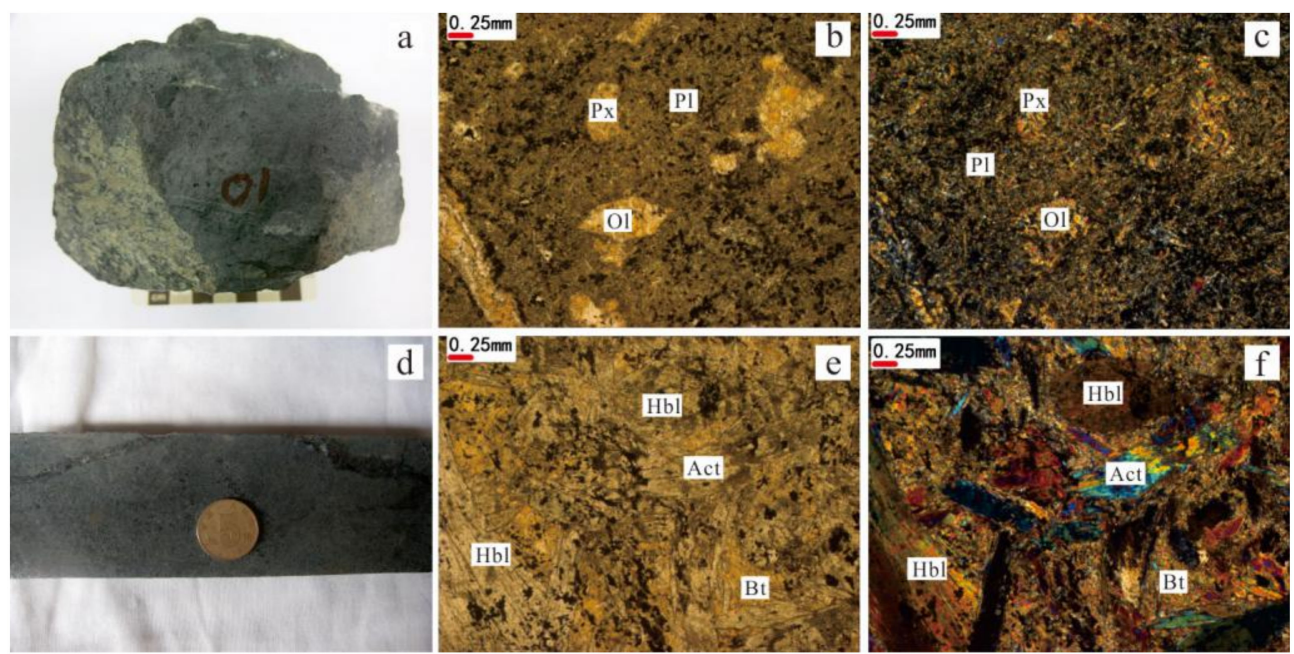

Figure 2. Typical hand specimen (a,d), single-polarized (b,e), and cross-polarized (c,f) light photomicrographs of basalts in Qilinshan $(\mathbf{a}-\mathbf{c})$ and Laochang $(\mathbf{d}-\mathbf{f})$. Px-pyroxene, Pl—plagioclase, $\mathrm{Hbl}$-hornblende, Ol—olivine, $\mathrm{Bt}$ - biotite, Act—actinolite.

\section{Methods}

\subsection{Zircon LA-ICP-MS Analyses}

Thirty kilos of fresh basalts sample were collected to pick up zircons. The rock was dark green in color and had an amygdaloidal structure. The surface of the sample was first washed clean with water and dried naturally. The sample was then crushed to 80 meshes. After coarse washing with water, strong magnetic separation, electromagnetic separation, and fine washing with alcohol, the zircons were hand-picked under a double microscope.

Zircon U-Pb analyses were conducted at the Key Laboratory of Crust-Mantle Materials and Environments, University of Science and Technology of China. U-Pb abundance was measured using the latest Neptune Plus multiple collectors (ICP-MS) from Thermo Fisher Co. Ltd (Waltham, MA, 
USA). The laser-ablation system used in the measurement was the GeoLasPro $193 \mathrm{~nm}$ developed by the Coherent Co. Ltd (Santa Clara, CA, USA). Helium was used as a carrier gas to enhance transport efficiency of ablated material. The spot size of the laser ablation beam was $32 \mu \mathrm{m}$. The LA-ICP-MS operating conditions were optimized based on measurements of the reference material zircon 91500 . The accuracy of the data was verified by using GJ-1 as an auxiliary standard. The LA-ICP-MS measurement was carried out using time-resolved analysis operated in fast peak-hopping and DUAL detector mode with a short integration time. The Harvard standard zircon 91500 and GJ-1 were measured after every 5 to 10 sample spots, to ensure no drift was occurring. The data were analyzed in the ICPMSDataCal program [28] and the Isoplot program [29].

\subsection{Major and Trace Element Analyses}

Bulk-rock major and trace element compositions of the samples were measured at the Testing Center of Rock and Mineral in Henan province. The major elements were analyzed using a ZSX100e (Rigaku Co., Akishima, Tokyo, Japan) X-ray fluorescence spectrometer (XRF) on fused glass beads. The trace elements, including rare earth elements, were measured by inductively coupled plasma mass spectrometry (ICP-MS) with an XSERIES2 (Thermo Fisher Co. Ltd, Waltham, MA, USA). A detailed methodology of the analytical procedures can be found in Gao [30]. The analyses of the international standards returned values that agreed with their published values. Analyses of the international rock standards indicated that the precision and accuracy were better than $1.5 \%$ for all elements.

\subsection{Whole Rock $\mathrm{Sr}-\mathrm{Nd}-\mathrm{Pb}$ Isotopic Analyses}

The Sr-Nd isotope analyses were carried out at the Ministry of Education Key Laboratory of Orogenic Belts and Crustal Evolution, Peking University. Powdered bulk-rock samples were first spiked with mixed isotope tracers and then dissolved in a solution of HF and HNO3 in Teflon capsules before undergoing $\mathrm{Rb}-\mathrm{Sr}$ and $\mathrm{Sm}-\mathrm{Nd}$ isotope analyses. $\mathrm{Rb}, \mathrm{Sr}, \mathrm{Sm}$, and $\mathrm{Nd}$ were separated using conventional ion exchange procedures, as described by Yan [31]. The Sr-Nd isotopic data were measured on a VG Axiom mass spectrometer. The $\mathrm{Nd}$ and $\mathrm{Sr}$ ratios were normalized to ${ }^{146} \mathrm{Nd} /{ }^{144} \mathrm{Nd}=0.7219$ and ${ }^{86} \mathrm{Sr} /{ }^{88} \mathrm{Sr}=0.1194$, respectively. The BCR-2 standards, which were ${ }^{143} \mathrm{Nd} /{ }^{144} \mathrm{Nd}=0.512633 \pm 0.000017$ $(2 \sigma)$ and ${ }^{87} \mathrm{Sr} /{ }^{86} \mathrm{Sr}=0.705013 \pm 0.000019(2 \sigma)$, respectively, were used to assess analytical precision.

The $\mathrm{Pb}$ isotope analyses were tested at the Beijing Institute of Uranium Geology using a Isoprobe- $\mathrm{T}$ (GV, Manchester, UK) thermal ionization mass spectrometer (TIMS). These samples were first placed in crucibles and dissolved in $\mathrm{HF}$ and $\mathrm{HClO} 4$, then the purified $\mathrm{Pb}$ was extracted using basic anion exchange resin [32]. Analytical results for the NBS981 standard agreed with the reference value [33].

\section{Results}

\subsection{Zircon $\mathrm{U}-\mathrm{Pb}$ Dating}

The LA-ICP-MS zircon U-Pb dating results are listed in Table 1. The sample ISKB-01 was collected from Qilinshan that was located at $22^{\circ} 19^{\prime} 40^{\prime \prime} \mathrm{N}, 103^{\circ} 16^{\prime} 43^{\prime \prime}$ E. Twenty-five zircon grains were picked out from sample ISKB-01.

The majority of the zircon grains separated from the sample were light gray in color, euhedral in shape, and transparent in opacity under the microscope (Figure 3a). The grains were 50 to $200 \mu \mathrm{m}$ long with elongation ratios ranging from 1:1 to 3:1. Almost all of the zircons exhibited oscillatory zoning in CL, implying a magmatic origin. The Th and $U$ concentrations were 36.38 to $669.17 \mathrm{ppm}$ and 71.73 to $721.1 \mathrm{ppm}$, respectively, with $\mathrm{Th} / \mathrm{U}$ ratios ranging from 0.86 to 2.75 . Twenty-five spots were tested, and all were from a single age group clustered in 256 to $237 \mathrm{Ma}$; the spots yielded a weighted mean ${ }^{206} \mathrm{~Pb} /{ }^{238} \mathrm{U}$ age of $244 \mathrm{Ma}(\mathrm{MSWD}=4.9$ ) (Figure $3 \mathrm{~b}$ ). This age is considered to represent the crystallization age of the magmatic zircons. 

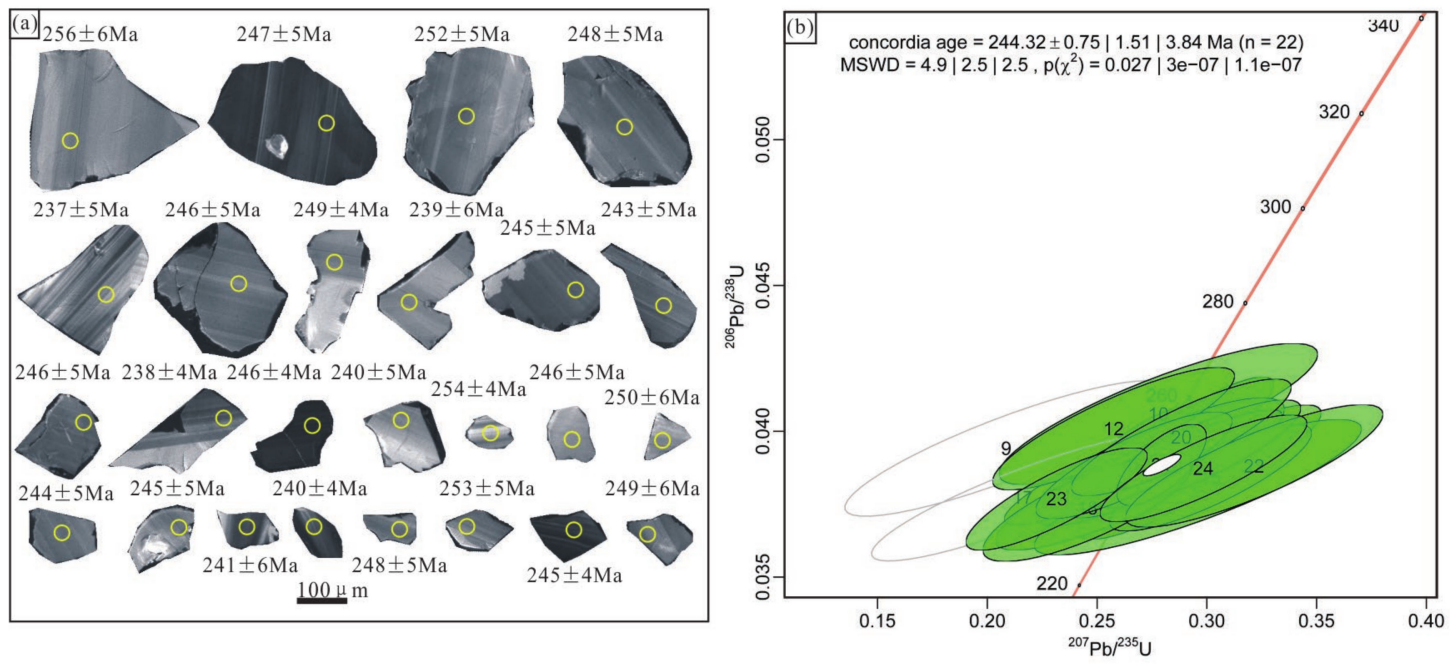

Figure 3. (a) Cathodoluminescence (CL) images of the selected zircons for LA-ICP-MS dating; (b) Concordia diagram of zircon $\mathrm{U}-\mathrm{Pb}$ age for the Qilinshan basalts.

Table 1. U-Pb isotopic compositions for zircon from Qilinshan basalts sample ISKB-01.

\begin{tabular}{|c|c|c|c|c|c|c|c|c|c|c|c|}
\hline \multirow{2}{*}{ Spot } & \multirow{2}{*}{$\begin{array}{c}\text { Th } \\
\text { (ppm) }\end{array}$} & \multirow{2}{*}{$\begin{array}{c}\mathrm{U} \\
(\mathrm{ppm})\end{array}$} & \multirow{2}{*}{$\begin{array}{l}\text { Th/U } \\
\text { Ratio }\end{array}$} & \multicolumn{2}{|c|}{${ }^{207} \mathrm{~Pb} /{ }^{206} \mathrm{~Pb}$} & \multicolumn{2}{|c|}{${ }^{207} \mathrm{~Pb} /{ }^{235} \mathrm{U}$} & \multicolumn{2}{|c|}{${ }^{206} \mathrm{~Pb} /{ }^{238} \mathrm{U}$} & \multicolumn{2}{|c|}{${ }^{206} \mathrm{~Pb} /{ }^{238} \mathrm{U}$} \\
\hline & & & & Ratio & $1 \sigma$ & Ratio & $1 \sigma$ & Ratio & $1 \sigma$ & Age & $1 \sigma$ \\
\hline KB1-1 & .92 & & 5 & 0.05343 & 0.00316 & 0.27953 & 0.01568 & 0.03798 & 0.00069 & 240 & 4.3 \\
\hline KB1-2 & & & & 56 & 2 & 0.25 & 0 & 98 & 4 & & 5.19 \\
\hline KB1-3 & & 14 & & 8 & 0 & 0.27 & 45 & 0.03 & 7 & & 77 \\
\hline KB1-4 & 17 & & 7 & 1 & 5 & 1 & 64 & 12 & 3 & & \\
\hline KB1-5 & & & & & 8 & 0.29 & 9 & 22 & 7 & & 14 \\
\hline KB1-6 & & & & & & 0 & 0 & 9 & 4 & & 82 \\
\hline KB1-7 & 40 & & & & 0 & 0 & 0 & 8 & 5 & 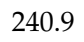 & 91 \\
\hline KB1-8 & 182.34 & 280 & & 6 & 0.0 & 0.27 & 0.0 & 8 & 5 & 2 & 04 \\
\hline KB1-9 & 50.75 & 9 & 1. & 9 & 0.0 & 0.26 & 0.0 & 39 & 0.0 & 2 & 35 \\
\hline KB1-10 & 37 & 7 & 6 & 42 & 0.00 & 0.20861 & 0.03004 & 0.03 & 0.00 & 249 & .88 \\
\hline KB1-11 & 36.38 & 7 & 7 & 67 & 0.00 & 0.27787 & 0.02968 & 0.0 & 0.00 & 2 & 6.12 \\
\hline KB1-12 & 50.71 & 139.24 & 5 & 0.05 & 0.00389 & 0.28581 & 0.02024 & 0.03924 & 0.00078 & 2 & 4.86 \\
\hline KB1-13 & 41.08 & 109.27 & 8 & 0.04661 & 0.004 & 0.25 & 0.02254 & 0.04009 & 0.00086 & 25 & 5.36 \\
\hline KB1-14 & 391.5 & 33 & 8620434 & 05247 & 0.00231 & 0.28027 & 0.01134 & 0.03876 & 0.00062 & 24 & 3.83 \\
\hline KB1-15 & 53.54 & 134.48 & 69 & 336 & 0.00384 & 0.28594 & 0.01977 & 0.03888 & 0.00076 & 245.9 & 4.74 \\
\hline KB1-16 & $57.9 ?$ & 14 & 234 & 8 & 0.00373 & 0.30168 & 0.01882 & 0.03841 & 0.00075 & 24 & 4.68 \\
\hline $1-17$ & 50.91 & 130.3 & 2 & 9 & 0.00377 & 0.29512 & 0.0 & 0.03922 & 0.00 & 24 & 4.72 \\
\hline $1-18$ & 41.8 & 81.05 & & 5 & $0 .($ & 0.21 & 0.0 & 0.0 & 0.0 & 23 & 5.56 \\
\hline $\mid-1$ & 112.9 & & & 7 & 0.0 & 0.24 & 0.0 & 0.0 & 0.0 & 23 & 4.68 \\
\hline $\mathrm{K}$ & 57.6 & 1 & 2 & 4 & 0.00 & 0.26679 & 0.0 & 0.0 & 0.00 & 2 & .64 \\
\hline-21 & 4 & 1 & 1 & 6 & 0.00389 & 0.28834 & 0.02049 & 0.03979 & 0.00082 & 2 & .08 \\
\hline KB1-22 & 669.17 & 721.1 & 1.0776036 & 05215 & 0.00177 & 0.27938 & 0.00836 & 0.03885 & 0.00057 & 245.7 & 3.52 \\
\hline KB1-23 & 48.31 & 92.96 & 1.9242393 & 0.06008 & 0.00467 & 0.32154 & 0.02398 & 0.03881 & 0.00086 & 245.5 & 5.32 \\
\hline KB1-24 & 109.27 & 141.25 & 1.2926695 & 0.04457 & 0.00337 & 0.23159 & 0.0169 & 0.03768 & 0.00072 & 238.5 & 4.47 \\
\hline KB1-25 & 45.9 & 120.01 & 2.614597 & 0.05587 & 0.00378 & 0.29842 & 0.01929 & 0.03873 & 0.00075 & 245 & 4.67 \\
\hline
\end{tabular}

\subsection{Whole Rock Geochemistry}

Fifty samples were measured for major and trace element analyses (Supplementary Material, Table S1). These samples were collected from Qilinshan and Laochang, respectively. Almost all the samples showed different degrees of alteration with a large variation in loss on ignition (LOI) (1.35-9.08 wt.\%), demonstrating relatively strong alteration.

For the samples from Qilinshan, the $\mathrm{SiO}_{2}$ content ranged from 40 to $48.68 \mathrm{wt} . \%$. Most rocks plotted fell in the alkaline basalts field, as seen in Figure $4 \mathrm{a}, \mathrm{b}$, and belonged to the potassic and sodic series (Figure 4c). These rocks had high $\mathrm{TiO}_{2}$ contents (2.14-3.23 wt.\%), with the $\mathrm{TiO}_{2}$ contents of most samples being larger than 2.5, and belonging to the high-Ti basalts (Figure 4d), as defined by Xu [34]. 
The $\mathrm{MgO}$ contents were 7.76-13.92 wt.\% and the $\mathrm{Mg \#}=53.27-67.77$, which is characteristic of primary magma. The $\mathrm{TFe}_{2} \mathrm{O}_{3}$ content ranged from 10.18 to $16.06 \mathrm{wt}$ \% $\%$. The $\mathrm{K}_{2} \mathrm{O}$ contents $(0.22-2.31$ wt. $\%)$ in Qilinshan basalts were much lower than that in Laochang basalts. The LILEs were enriched relative to the HFSEs. The $(\mathrm{La} / \mathrm{Yb})_{\mathrm{N}}$ ratios varied from 8.20 to 23.68 (mean value $=13.34$ ). As revealed by the primitive mantle normalized trace element diagram and the chondrite normalized rare earth element (REE) diagram (Figure 5), the patterns of the Qilinshan basalts were similar to the Emeishan basalts and strongly resembled those of OIB.
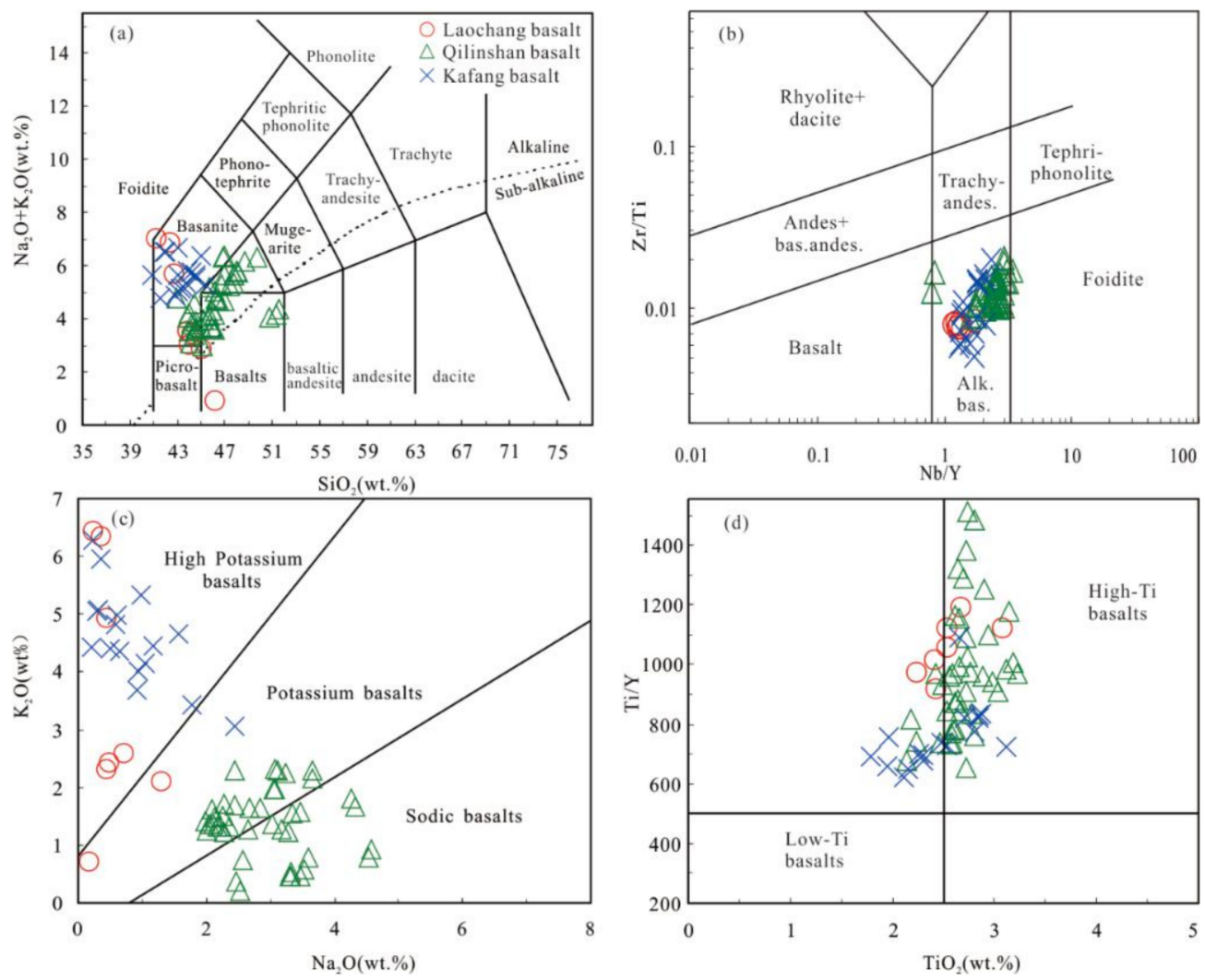

Figure 4. (a): $\mathrm{SiO}_{2}$ vs. $\mathrm{Na}_{2} \mathrm{O}+\mathrm{K}_{2} \mathrm{O}$ classification diagram; (b): $\mathrm{Nb} / \mathrm{Y}$ vs. $\mathrm{Zr} / \mathrm{Ti}$ diagram; (c): $\mathrm{Na}_{2} \mathrm{O}$ vs. $\mathrm{K}_{2} \mathrm{O}$ classification diagram; (d): $\mathrm{TiO}_{2}$ vs. Ti/Y diagram. The data of Kafang from [16].

The Laochang basalt samples had extremely low $\mathrm{SiO}_{2}$ contents (39.33-44.49 wt.\%). Most samples fell in the basanite and basalt areas in Figure $4 a$, and belonged to high-Ti alkaline basalts in Figure 4b,d. In the diagram showing $\mathrm{Na}_{2} \mathrm{O}$ vs. $\mathrm{K}_{2} \mathrm{O}$, the rocks had high-K characteristics (Figure $4 \mathrm{c}$ ). $\mathrm{The}^{\mathrm{TiO}} \mathrm{O}_{2}$ content ranged from 2.24 to 3.07 wt.\%. The Laochang basalts had higher MgO content (12.16-19.58 wt.\%) and Mg\# values (64.39-76.95) relative to those of the Qilinshan basalts. The contents of $\mathrm{TFe}_{2} \mathrm{O}_{3}$ and $\mathrm{K}_{2} \mathrm{O}$ were 11.05-14.02 wt.\% and 2.12-6.45 wt.\%, respectively, for the Laochang basalts. For the trace elements and REEs, the $(\mathrm{La} / \mathrm{Yb})_{\mathrm{N}}$ ratios varied from 7.43 to 18.96 (mean value $=12.24$ ). These samples exhibited strongly positive $\mathrm{Rb}$ anomalies and negative $\mathrm{Ba}$ anomalies in the primitive mantle normalized trace element diagram (Figure 5). As can be seen in Figure 5, the patterns of immobile elements in Laochang and Kafang basalts were consistent with those of Emeishan basalts and OIB. Mobile elements such as $\mathrm{Rb}, \mathrm{Ba}, \mathrm{Sr}, \mathrm{K}$, and $\mathrm{Pb}$ have high activities and are sensitive to physical and chemical alterations. Therefore, the abnormities of these elements in Laochang and Kafang may have resulted from the process of metamorphism and/or hydrothermal alteration. 

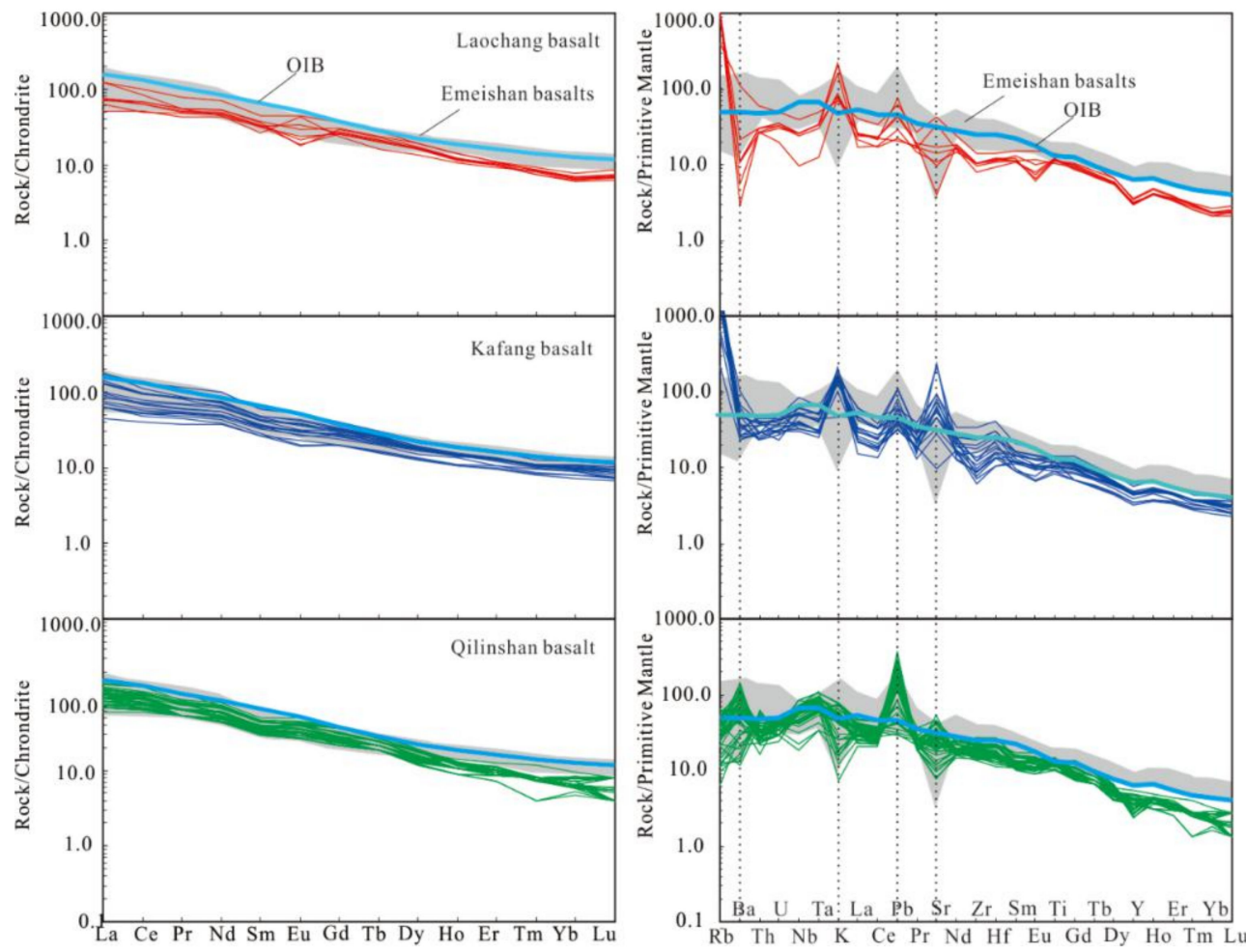

Figure 5. Chondrite normalized REE patterns and primitive mantle normalized trace element patterns of the GAAB. Normalization and OIB values followed [35]. The data of Emeishan basalts from [3]. The data of Kafang from [16].

\section{3. $\mathrm{Sr}-\mathrm{Nd}-\mathrm{Pb}$ Isotopic Geochemistry}

Whole-rock $\mathrm{Sr}-\mathrm{Nd}-\mathrm{Pb}$ isotopes of the samples from Qilinshan and Laochang are listed in Tables 2 and 3. The initial $\mathrm{Sr}-\mathrm{Nd}-\mathrm{Pb}$ isotopic ratios for all the samples were corrected to $244 \mathrm{Ma}$, according to our new zircon $\mathrm{U}-\mathrm{Pb}$ dating age. The initial ${ }^{87} \mathrm{Sr} /{ }^{86} \mathrm{Sr}$ values of Qilinshan basalts ranged from 0.7044 to 0.7047 with $\varepsilon \mathrm{Nd}(\mathrm{t})$ values ranging from 4.69 to 4.92 . The Laochang basalts had smaller initial ${ }^{87} \mathrm{Sr} /{ }^{86} \mathrm{Sr}$ values (0.7044-0.7048) and $\varepsilon \mathrm{Nd}(\mathrm{t})$ values (3.25-3.43). Lead isotopes are more complex because $\mathrm{U}$, $\mathrm{Th}$, and $\mathrm{Pb}$ are all mobile during alteration. The initial ${ }^{206} \mathrm{~Pb} /{ }^{204} \mathrm{~Pb},{ }^{207} \mathrm{~Pb} /{ }^{204} \mathrm{~Pb}$, and ${ }^{208} \mathrm{~Pb} /{ }^{204} \mathrm{~Pb}$ ratios in Qilinshan basalts were 17.493-18.150, 15.530-15.613, and 37.713-38.853, respectively, and 17.976-18.197, 15.683-15.722, and 38.501-38.713 in Laochang basalts, respectively. 
Table 2. Sr-Nd isotopic compositions of Qilinshan and Laochang basalts.

\begin{tabular}{|c|c|c|c|c|c|c|c|c|c|c|}
\hline Sample & Age(Ma) & $\mathrm{Rb}(\mathrm{ppm})$ & Sr(ppm) & ${ }^{87} \mathrm{Sr} /{ }^{86} \mathrm{Sr}$ & $\left({ }^{87} \mathrm{Sr} /{ }^{86} \mathrm{Sr}\right) \mathrm{i}$ & Sm(ppm) & $\mathrm{Nd}(\mathrm{ppm})$ & ${ }^{143} \mathrm{Nd} /{ }^{144} \mathrm{Nd}$ & $\left({ }^{143} \mathrm{Nd} /{ }^{144} \mathrm{Nd}\right) \mathrm{i}$ & $\varepsilon N d(t)$ \\
\hline Laochang-01 & 244 & 637 & 292.1 & 0.7263 & 0.7044 & 4.92 & 22.00 & 0.51272 & 0.51250 & 3.43 \\
\hline Laochang-02 & 244 & 710 & 83.0 & 0.7905 & 0.7048 & 5.46 & 24.61 & 0.51270 & 0.51249 & 3.25 \\
\hline Qilinshan-8 & 244 & 17 & 395.1 & 0.7052 & 0.7047 & 6.70 & 33.31 & 0.51276 & 0.51256 & 4.69 \\
\hline Qilinshan-9 & 244 & 13 & 549.0 & 0.7047 & 0.7044 & 6.56 & 31.07 & 0.51278 & 0.51257 & 4.92 \\
\hline
\end{tabular}

Table 3. Pb isotopic compositions of Qilinshan and Laochang basalts.

\begin{tabular}{|c|c|c|c|c|c|c|c|c|c|c|}
\hline Sample & Age (Ma) & ${ }^{206} \mathrm{~Pb} /{ }^{204} \mathrm{~Pb}$ & ${ }^{207} \mathrm{~Pb} /{ }^{204} \mathrm{~Pb}$ & ${ }^{208} \mathrm{~Pb} /{ }^{204} \mathrm{~Pb}$ & $\left({ }^{206} \mathrm{~Pb} /{ }^{204} \mathrm{~Pb}\right) \mathrm{t}$ & $\left({ }^{207} \mathrm{~Pb} /{ }^{204} \mathrm{~Pb}\right) \mathrm{t}$ & $\left({ }^{208} \mathrm{~Pb} /{ }^{204} \mathrm{~Pb}\right) \mathrm{t}$ & $\Phi$ & $\mu$ & $\mathrm{Th} / \mathrm{U}$ \\
\hline Laochang-01 & 244 & $18.554 \pm 0.007$ & $15.701 \pm 0.005$ & $39.106 \pm 0.014$ & 18.197 & 15.683 & 38.713 & 0.585 & 9.65 & 3.95 \\
\hline Laochang-02 & 244 & $18.658 \pm 0.004$ & $15.757 \pm 0.004$ & $39.252 \pm 0.007$ & 17.976 & 15.722 & 38.501 & 0.584 & 9.75 & 3.97 \\
\hline Qilinshan-08 & 244 & $18.780 \pm 0.006$ & $15.645 \pm 0.006$ & $39.282 \pm 0.016$ & 18.150 & 15.613 & 38.853 & 0.565 & 9.52 & 3.89 \\
\hline Qilinshan-09 & 244 & $18.859 \pm 0.006$ & $15.600 \pm 0.005$ & $39.145 \pm 0.010$ & 17.493 & 15.530 & 37.713 & 0.556 & 9.42 & 3.79 \\
\hline
\end{tabular}




\section{Discussion}

\subsection{Magma Source}

In the past decade, the GAAB have attracted a lot of attention for its close relationship with the $\mathrm{Cu}$ deposits in the Gejiu ore district $[22,36]$. However, relatively little research has focused on how the GAAB were formed. For this reason, the magma source of the GAAB remain unresolved. While it is widely accepted that these basalts were the product of the melting of mantle peridotite, the identification of the mantle source has been proven difficult because of the complexity of lithospheric mantle [37]. The Sr-Nd-Pb isotopic characteristics of igneous rocks can often narrow the potential source regions of basalts because isotopic fractionation is not affected by magma crystallization and segregation in the magmatic process. The $\mathrm{Sr}$ and $\mathrm{Nd}$ isotopic characteristics of the GAAB were consistent, the initial ${ }^{87} \mathrm{Sr} /{ }^{86} \mathrm{Sr}=0.7044-0.7048$ and ${ }^{143} \mathrm{Nd} /{ }^{144} \mathrm{Nd}=0.51249-0.51257$, and the $\mathrm{Pb}$ isotopes exhibited an appropriate variation range. In the diagram of $\left({ }^{87} \mathrm{Sr} /{ }^{86} \mathrm{Sr}\right) \mathrm{i}$ vs. $\varepsilon \mathrm{Nd}(\mathrm{t})$ (Figure 6a), all of the samples fell in the field of the Emeishan flood basalts and showed similarities with the OIB. Moreover, $\mathrm{Pb}$ isotopes also showed similar characteristics to Emeishan flood basalts (Figure 6b). The $\mathrm{Sr}-\mathrm{Nd}-\mathrm{Pb}$ isotopic data indicated that the GAAB were derived from the same OIB-like source as the Emeishan flood basalts.
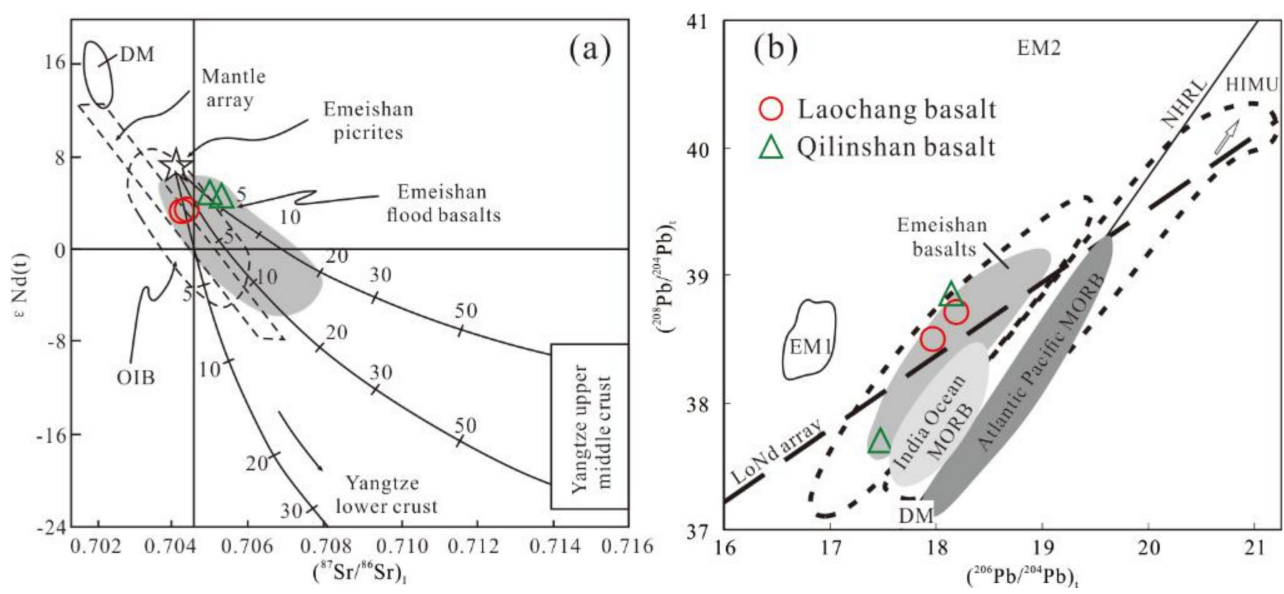

Figure 6. (a) $\left({ }^{87} \mathrm{Sr} /{ }^{86} \mathrm{Sr}\right) \mathrm{i}$ vs. $\varepsilon \mathrm{Nd}(\mathrm{t})$ diagram (modified from [3]), OIB: ocean island basalt; (b) $\left({ }^{206} \mathrm{~Pb} /{ }^{204} \mathrm{~Pb}\right)$ t vs. $\left({ }^{208} \mathrm{~Pb} /{ }^{204} \mathrm{~Pb}\right) \mathrm{t}$ diagram $(t=244 \mathrm{Ma}$, modified from [38]), EM1: enriched mantle 1, EM2: enriched mantle 2, DM: depleted mantle, HIMU: high ${ }^{238} \mathrm{U} /{ }^{204} \mathrm{~Pb}$ mantle end member, NHRL: northern Hemisphere reference line; data of Emeishan basalts from [27].

Typically, the ratios of incompatible elements that share similar characteristics in the mantle (such as $\mathrm{Zr} / \mathrm{Nb}$ and $\mathrm{Nb} / \mathrm{Th}$ ) are not strongly fractionated from each other during the process of partial melting or fractional crystallization. Hence, their ratios can be used to identify the source of magma [39,40]. The $\mathrm{Nb}$ /Th ratio is insensitive to various degrees of melting of garnet lherzolite, while the $\mathrm{Zr} / \mathrm{Nb}$ ratio is moderately affected by different degrees of melting [40]. Therefore, the mantle source can be determined by comparing the $\mathrm{Nb} / \mathrm{Th}$ and $\mathrm{Zr} / \mathrm{Nb}$ ratios (Figure $7 \mathrm{a}$ ). Most of the samples fell in the field near OIB, implying that the GAAB were derived from an enriched mantle sources similar to that of OIB.

Magma sources can also be identified by their $\mathrm{Nb} / \mathrm{Y}$ and $\mathrm{Zr} / \mathrm{Y}$ ratios, this is because of their predictability during the partial melting and fractional crystallization processes [41]. Thus, Fitton [42] proposed the formula: $\delta \mathrm{Nb}=\log (\mathrm{Nb} / \mathrm{Y})+1.74-1.92 \times \log (\mathrm{Zr} / \mathrm{Y})$, based on the $\mathrm{Nb} / \mathrm{Y}$ and $\mathrm{Zr} / \mathrm{Y}$ ratios. When $\delta \mathrm{Nb}>0$, the magma is related to an enriched mantle, but when $\delta \mathrm{Nb}<0$, the magma is related to a depleted mantle. Almost all of the samples had $\delta \mathrm{Nb}>0$, indicating an enriched mantle source. Likewise, enriched mantle sources can be identified by comparing $\mathrm{Zr} / \mathrm{Y}$ and $\mathrm{Nb} / \mathrm{Y}$ (Figure $7 \mathrm{~b}$ ). 
These comparisons revealed that the majority of the samples fell in the OIB field, indicating the GAAB were derived from enriched mantle.
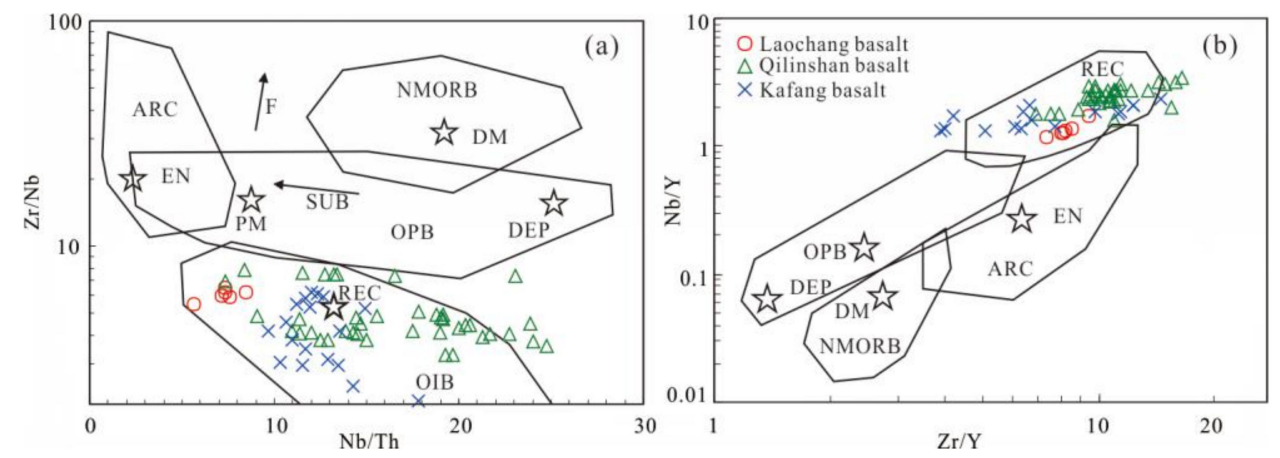

Figure 7. Diagram showing mantle components and fields for basalts from various tectonic settings [40,42]. (a) $\mathrm{Nb} / \mathrm{Th}$ vs. $\mathrm{Zr} / \mathrm{Nb}$, SUB: subduction; (b) $\mathrm{Zr} / \mathrm{Y}$ vs. Nb/Y. NMORB: normal mid ocean ridge basalts, DM: depleted mantle, REC: recycled components, EN: enriched, DEP: depleted components, ARC: arc basalts, OPB: oceanic plateau and island basalts. The data of Kafang from [16].

HFSEs and REEs are immobile during the alteration and weathering processes [43-45]. Therefore, the contents and ratios of light REEs and HFSEs are widely used to distinguish between magma sources and determine the degree of partial melting $[46,47]$. In the diagram showing $\mathrm{La} / \mathrm{Nb} \mathrm{vs}$. La/Ba (Figure 8a), most samples can be seen to fall in the field of asthenosphere and OIB, with no indicators for crust contamination. Relative to heavy REEs (such as $\mathrm{Yb}$ ), the enrichment of middle REEs (such as Sm) depends on the presence of garnet in the residual phase during the melting process. Sm is incompatible with garnet, whereas $\mathrm{Yb}$ is compatible, this means that the ratio of $\mathrm{Sm} / \mathrm{Yb}$ can be intensely fractionated when there is a low degree of melting. Accordingly, using Sm vs. Sm/Yb, the degree of partial melting of the mantle source can be constrained using the non-modal batch melting equations [48,49]. Most of the samples had high $\mathrm{MgO}$ content (>8 wt.\%), which could indicate that the historical source of the basaltic magma underwent partial melting [3]. As can be seen in Figure 8b, the GAAB originated from $5 \%$ to $15 \%$ partial melting of garnet lherzolite.
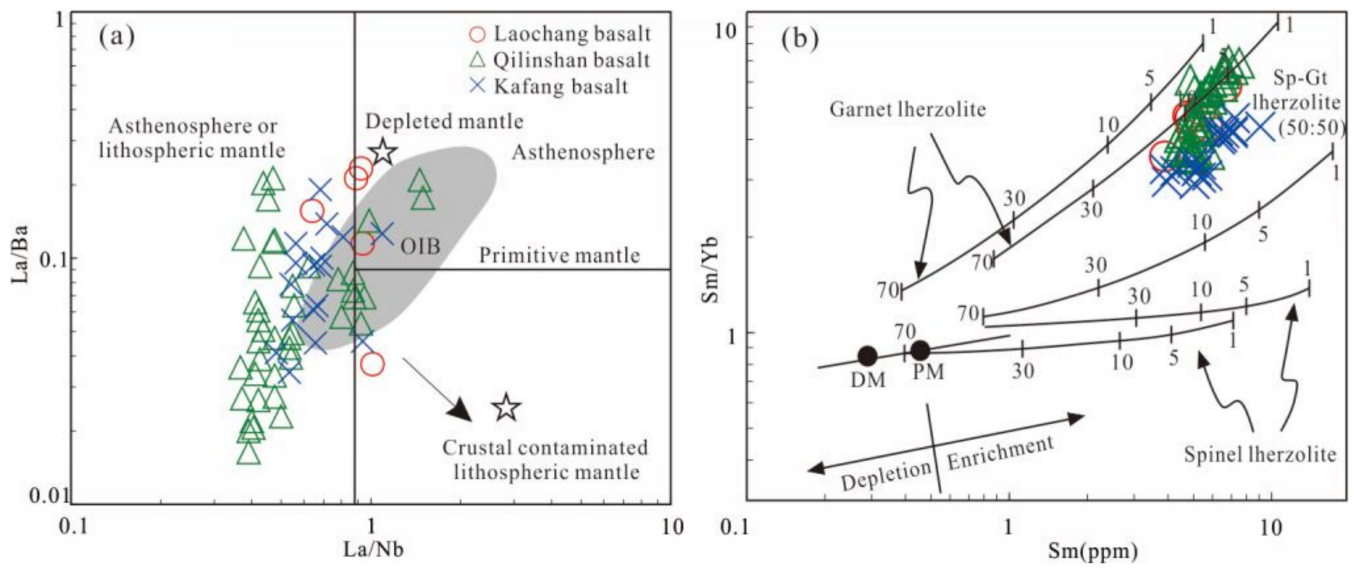

Figure 8. (a): La/Nb vs. La/Ba diagram (modified from [50]); (b): Sm vs. Sm/Yb diagram (modified from [3]). The data of Kafang from [16].

Generally, the $\mathrm{TiO}_{2}$ content in magma from the asthenosphere is about $1.27 \mathrm{wt} . \%$, while in magma from deeper mantle material it is generally more than $2 \mathrm{wt} . \%$ [37]. The GAAB had high $\mathrm{TiO}_{2}$ content $\left(\mathrm{TiO}_{2}>2\right.$ wt.\%), similar to the representative OIB $\left(\mathrm{TiO}_{2}=2.87 \mathrm{wt} . \%\right.$; [41]), and the Ti/Y ratios ranged from 620 to 1533, similar to the Emeishan high-Ti basalts [34], indicating they derived from the deeper enriched mantle. The OIB-like basalts studied here suggested that there was a period of within plate 
magmatism in the South China Block around $244 \mathrm{Ma}$. In the diagram of $\left({ }^{87} \mathrm{Sr} /{ }^{86} \mathrm{Sr}\right) \mathrm{i}$ vs. $\left({ }^{143} \mathrm{Nd} /{ }^{144} \mathrm{Nd}\right) \mathrm{t}$ (Figure 9f), the samples fell near the OIB field and displayed enriched mantle (EM1) evolutionary trends, which indicated they were related to an ancient subcontinental lithospheric mantle (SCLM) metasomatized by a small volume of volatile-enriched melt that originated from asthenosphere or deeper mantle [51-53]. As described above, based on the combination of geochemical and isotopic characteristics of the GAAB, it can be concluded that the GAAB were mainly derived from deeper enriched mantle material and experienced $5 \%$ to $15 \%$ partial melting of garnet lherzolite.

\subsection{Petrogenesis}

Parental magma compositions are determined by the nature of the mantle source, conditions during mantle melting, fractional crystallization, and the extent of crustal contamination [7]. REEs, HFSEs, and $\mathrm{Sr}-\mathrm{Nd}-\mathrm{Pb}$ isotope compositions are commonly used to estimate these variables for a given sample. Using basaltic magma, the conditions during mantle melting can be investigated to provide information about the processes by which they formed [54]. Although alteration is pervasive in the GAAB, the abundances of compatible and incompatible elements in basaltic melts are not strongly influenced by alteration or weathering [54], so they can still serve as accurate indicators of historical conditions.

A low degree of partial melting of pyrolite can lead to the enrichment of incompatible elements, but with an increasing degree of melting, the enrichment of incompatible elements is reduced. Light REEs and highly incompatible elements are mainly enriched in alkaline basalts with low $\mathrm{SiO}_{2}$ content. Evidence has shown that alkaline basalts are always generated by $2 \%$ to $10 \%$ partial melting of the incompatible elements enriched mantle source [55-57]. The GAAB had trace element compositions and light REEs signatures similar to the OIB. The enrichment of the trace elements and light REEs indicated that the degree of partial melting was less than $10 \%$. This conclusion can also be supported by the diagram of $\mathrm{Sm} v \mathrm{vs} . \mathrm{Sm} / \mathrm{Yb}$ (Figure $8 \mathrm{~b}$ ).
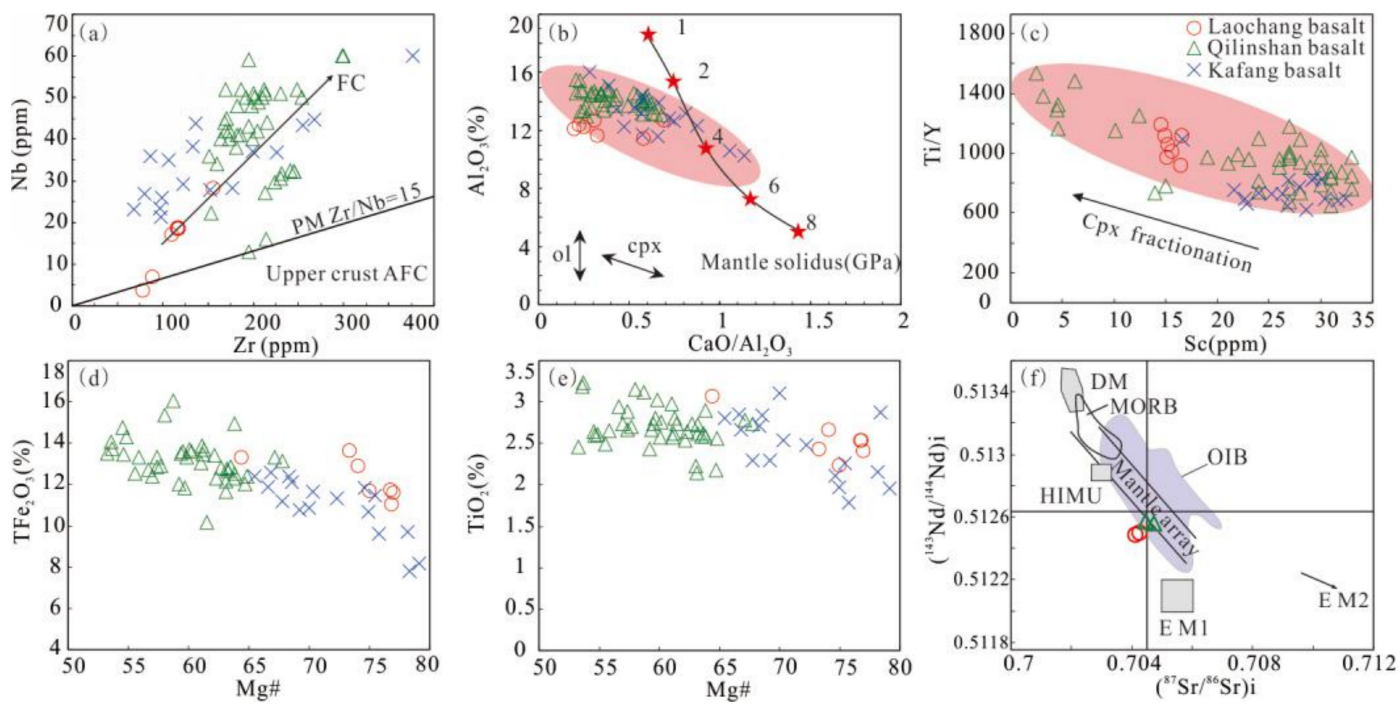

Figure 9. (a) $\mathrm{Zr}$ vs. $\mathrm{Nb}$ diagram (modified from [58]); (b) $\mathrm{CaO} / \mathrm{Al}_{2} \mathrm{O}_{3}$ vs. $\mathrm{Al}_{2} \mathrm{O}_{3}$ diagram (modified from [40]), ol: olivine, cpx: clinopyroxene; (c) Sc vs. Ti/Y diagram (modified from [7]); (d) Mg\# vs. $\mathrm{TFe}_{2} \mathrm{O}_{3}$ diagram; (e) $\mathrm{Mg \#}$ vs. $\mathrm{TiO}_{2}$ diagram; (f) $\left({ }^{87} \mathrm{Sr}{ }^{186} \mathrm{Sr}\right) \mathrm{i}$ vs. $\left({ }^{143} \mathrm{Nd} /{ }^{144} \mathrm{Nd}\right) \mathrm{i}$ (modified from [58]). The data of Kafang from [16].

Fractional crystallization (FC) is integral to magma evolution. Hence, it is always used to interpret geochemical characteristics observed in evolved volcanic rocks. As can be seen in the $\mathrm{Nb}$ vs. $\mathrm{Zr}$ plot in Figure 9a, the FC process existed. Moreover, the negative correlations that can be observed in the diagrams of $\mathrm{CaO} / \mathrm{Al}_{2} \mathrm{O}_{3}$ vs. $\mathrm{Al}_{2} \mathrm{O}_{3}$ (Figure 9b) and Sc vs. Ti/Y (Figure 9c) implied that the 
fractionation was of clinopyroxene, which was consistent with the petrographic features. Plagioclase fractionation appeared to be limited as there was no clear evidence for negative Eu anomalies, however most of the samples did have negative Sr anomalies (Figure 5). The near ubiquity of Sr anomalies might be attributed to the alteration or metamorphism during post-magmatic events. The negative correlations between $\mathrm{Mg \#}$ and $\mathrm{TFe}_{2} \mathrm{O}_{3}$ (Figure 9d) and between $\mathrm{Mg \#}$ and $\mathrm{TiO}_{2}$ (Figure 9e) indicated the fractionation of Ti-Fe oxides. Based on the experimentally determined mantle solidus $[40,59,60]$, magma segregation depth of basalts can be constrained by the $\mathrm{CaO} / \mathrm{Al}_{2} \mathrm{O}_{3}$ vs. $\mathrm{Al}_{2} \mathrm{O}_{3}$ diagram. As seen in Figure 9b, the melts segregation depth of the GAAB was between 2 and 4 GPa $(60-120 \mathrm{~km})$.

Crustal contaminated mafic melts have characteristically high initial ${ }^{87} \mathrm{Sr} /{ }^{86} \mathrm{Sr}$ ratios, low $\varepsilon \mathrm{Nd}(\mathrm{t})$ values, and negative $\mathrm{Nb}$ and Ta anomalies [61]. However, the GAAB had relatively low initial ${ }^{87} \mathrm{Sr} /{ }^{86} \mathrm{Sr}$ ratios, high $\varepsilon \mathrm{Nd}(\mathrm{t})$ values, and no $\mathrm{Nb}$ and $\mathrm{Ta}$ anomalies (Figure 5), which suggested that the crustal material in the magma was limited. Weak correlations between $\mathrm{SiO}_{2}$ and $\mathrm{La} / \mathrm{Nb}$ (Figure 10a) and the non-linear relationship between $\mathrm{SiO}_{2}$ and $\varepsilon \mathrm{Nd}(\mathrm{t})$ (Figure 10b) also indicated limited crustal contamination. The $\mathrm{Nb} / \mathrm{U}$ ratio in primary mantle-derived magma is always greater than 47 , and the $\mathrm{La} / \mathrm{Nb}$ and $\mathrm{La} / \mathrm{Ta}$ ratios are always smaller than 1.5 and 22 , respectively. These ratios can be used to identify the existence of crustal material due to their sensitivity to crustal contamination [62-64].
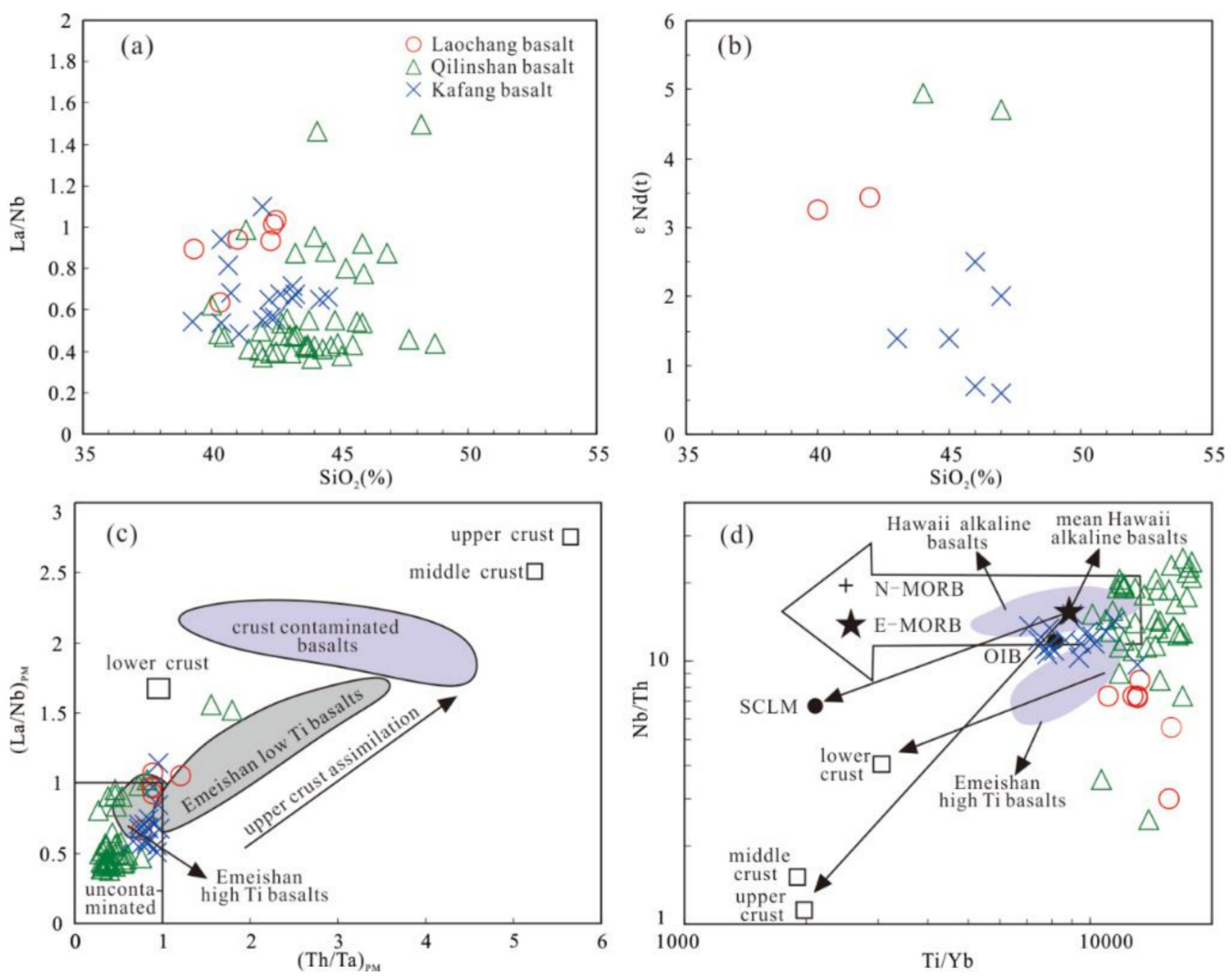

Figure 10. (a) $\mathrm{SiO}_{2}$ vs. $\mathrm{La} / \mathrm{Nb}$ diagram; (b) $\mathrm{SiO}_{2}$ vs. $\varepsilon \mathrm{Nd}(\mathrm{t})$ diagram; (c) $(\mathrm{Th} / \mathrm{Ta})_{\mathrm{PM}}$ vs. ( $\left.\mathrm{La} / \mathrm{Nb}\right)_{\mathrm{PM}}$ diagram (modified from [65]); (d) Ti/Yb vs. Nb/Th diagram (modified from [65]), N-MORB: Normal mid ocean ridge basalt, E-MORB: Enriched mid ocean ridge basalt. The data of Kafang from [16,21].

$\mathrm{The} \mathrm{Nb} / \mathrm{U}$ ratio in the GAAB was much higher than crustal material, but close to mantle-derived values. Likewise, the smaller $\mathrm{La} / \mathrm{Ta}$ and $\mathrm{La} / \mathrm{Nb}$ ratios $(\mathrm{La} / \mathrm{Ta} \leq 18 ; \mathrm{La} / \mathrm{Nb} \leq 1.46)$ in most samples revealed similarities with primary magma and also indicated limited crustal contamination. We can determine the existence of crustal material in mantle-derived magma using the diagram of $(\mathrm{Th} / \mathrm{Ta})_{\mathrm{PM}}$ vs. $(\mathrm{La} / \mathrm{Nb})_{\mathrm{PM}}$. As can be seen in Figure 10c, most of the samples fell in the uncontaminated field of the plot, showing there was little or no crustal material in the magma. These signatures indicate that the assimilation of crust during the generation of the basalts was insignificant, and therefore the chemical 
compositions of these basaltic rocks accurately reflect the characteristics of mantle source regions. $\mathrm{Nb} / \mathrm{Th}$ and $\mathrm{Ti} / \mathrm{Yb}$ ratios can be used to identify the lithospheric mantle materials in basalts [66]. In the diagram of $\mathrm{Ti} / \mathrm{Yb}$ vs. $\mathrm{Nb} / \mathrm{Th}$ (Figure 10d), most of the samples fell in the field of the OIB and showing evolutionary trends consistent with SCLM. OIB are widely believed to be related to hotspots or mantle plumes, which are usually imaged as columns of heated material ascending from the core-mantle boundary or mantle transition zone [67-72]. The upwelling of asthenospheric mantle or asthenospheric melts generated by rift events in an extensional regime can provide enough heat for the melting of the SCLM. In this case, the OIB-like magma mixed with the SCLM magma, which then formed the primary magma of the GAAB and experienced limited crustal contamination during the ascent.

\subsection{Tectonic Setting}

The tectonic setting of the GAAB is controversial and various viewpoints still receive support. For example, Zhang [21] proposed that the GAAB were generated in an epeiric sea semi-restricted gulf environment, Wang [13] concluded that these basalts were formed in an orogenic environment. The proposed tectonic settings of the GAAB also include within-plate extensional environment [14,15]; back-arc rift basin [16-19]; and decompressive melting of Emeishan plume head induced by a rift event $[20,21]$. To clarify the tectonic setting, we provided new zircon dating, major, trace element, and $\mathrm{Sr}-\mathrm{Nd}-\mathrm{Pb}$ isotopic data from these basaltic rocks collected from several representative outcrops and drillholes in the Gejiu ore district.

In Gejiu district, the Gejiu-Napo sedimentary basin has mainly occurred in the Triassic. The lower Triassic Yongningzhen and Feixianguan Formations are composed of shallow water clastic rocks containing fuchsia greywacke and conglomerate. The middle Triassic Gejiu Formation consists mainly of thick-bedded dolomite, limestone, and mudstone. The deposition depth of this sequence deepens gradually upward. The GAAB mainly occurred within the lower section of the Gejiu Formation. The upper Triassic sequence comprises macker and coarse clastic rocks. This sedimentary sequence is characterized by shallow water coarse-grained sediments, complex gravel composition, and coarse gravel sediments from deep to surface. The molasse facies of the sea-land interaction environment marked the shrinkage and closure of the rift basin. The thickness of the Triassic strata (approximately $4000 \mathrm{~m}$ ) increased dramatically in the Gejiu area [18]. The stratigraphic thickness thinned sharply on both the eastern and western sides of Gejiu (Figure 11). Besides, in Triassic, the bimodal magmatism is also developed in Gejiu district, including the alkaline basalt, dacite, and rhyolite [73]. The geological evidence indicates a rift-related volcanic-sedimentary event. Considering the zonal distribution of the sequence and the variation of stratigraphic thickness, the rift was likely controlled by a syngenetic fault.

Elements such as $\mathrm{Ti}, \mathrm{Zr}, \mathrm{Y}, \mathrm{Nb}, \mathrm{Hf}$ are useful in distinguishing basalts from different tectonic environments $[74,75]$. In the diagrams of $\mathrm{Nb}-\mathrm{Zr}-\mathrm{Y}$ (Figure 12a), Ti-Zr-Y (Figure 12b), and Hf-Th-Nb (Figure 12c), the majority of samples are distributed in the field of within-plate settings corresponding to the within-plate alkaline basalts. Moreover, the GAAB had characteristics of enrichment in light REEs, OIB-like geochemical signatures, and was similar to the high-Ti basalts of the ELIP. Young eruption age (244 Ma) excludes the possibility that the GAAB formed during the main event of ELIP (260-257 Ma) [76]. These basalts were coeval and genetically associated with the rift event in this area (Figure 11). Considering the facts described above, we propose that the GAAB erupted within the western margin of the South China Block in an extensional environment that was related to the Gejiu-Napo rift event in the Triassic. 


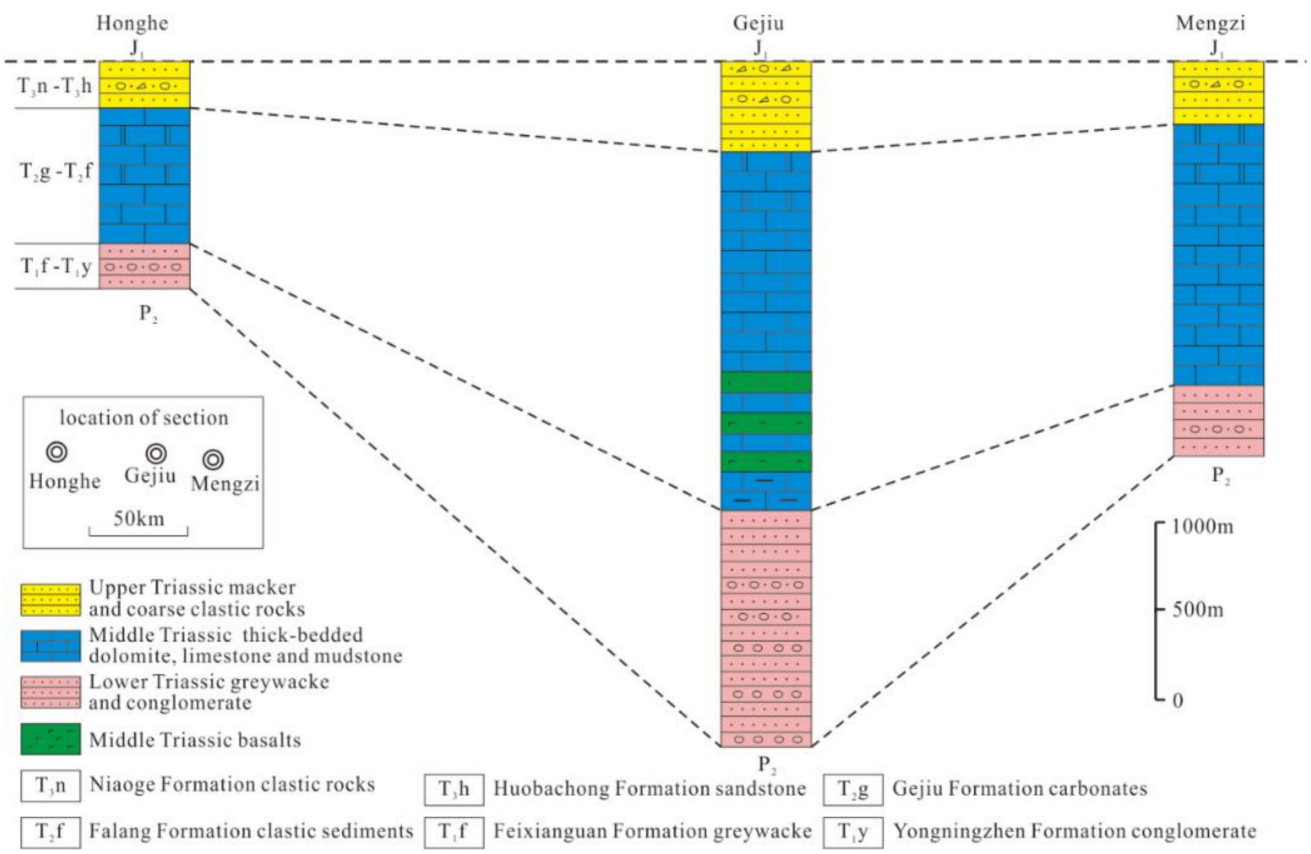

Figure 11. Stratigraphic correlation of the Triassic strata in the western South China block. The sedimentary data are from $[3,18,73]$.
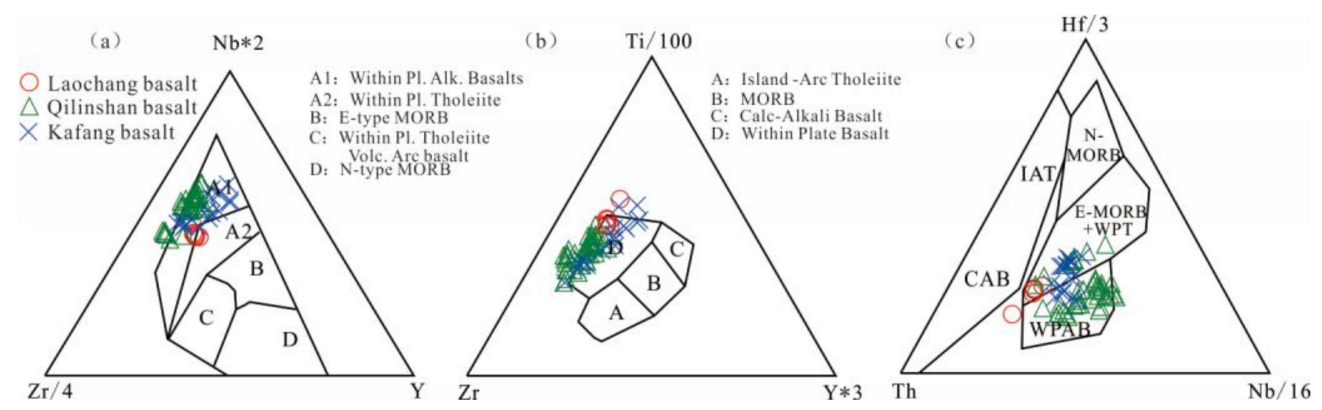

Figure 12. (a) $\mathrm{Nb}-\mathrm{Zr}-\mathrm{Y}$ diagram (modified from [74]); (b) Ti-Zr-Y diagram (modified from [75]); (c) Hf-Th- $\mathrm{Nb}$ diagram (modified from [77]), IAT: Island arc tholeiite, CAB: Calc-alkaline basalt, N-MORB: Normal mid ocean ridge basalt, E-MORB: Enriched mid ocean ridge basalt, WPT: Within plate tholeiite, WPAB: Within plate alkaline basalt. The data of Kafang from [16].

The Ailaoshan suture zone comprises several structurally juxtaposed tectonic units, including the Western Ailaoshan volcanic belts, Ailaoshan ophiolitic melange, Ailaoshan metamorphic complex from west to east [78-85]. Based on the comparison between the Permian and Triassic sedimentary rocks along the Ailaoshan suture zone, $\mathrm{Xu}$ [86] proposed they had different detrital provenance and formed in a depositional setting, which was likely caused by the closure of the Ailaoshan Ocean. Both the sedimentology and structural geology evidence show that the Ailaoshan suture zone has been a branch of the Paleo-Tethys Ocean and is the boundary between the South China Block and Indochina Block. The Paleo-Tethys Ailaoshan Ocean subducted beneath the Indochina Block in the Late Permian, and the onset of the collision between South China and Indochina blocks occurred in Early Triassic, around $250 \mathrm{Ma}$ [23]. The Phia Bioc granites (248-245 Ma), Tongtiange leucogranites ( 247 Ma), and rhyolites (247-246 Ma) in the Gaoshanzhai, Pantiange and formations are related to syn-collisional crust thickening [87-89]. The GAAB with the age of 244 Ma formed in the Gejiu-Napo rift basin were related to a post-collisional setting after the South China-Indochina collision (Figure 13). 


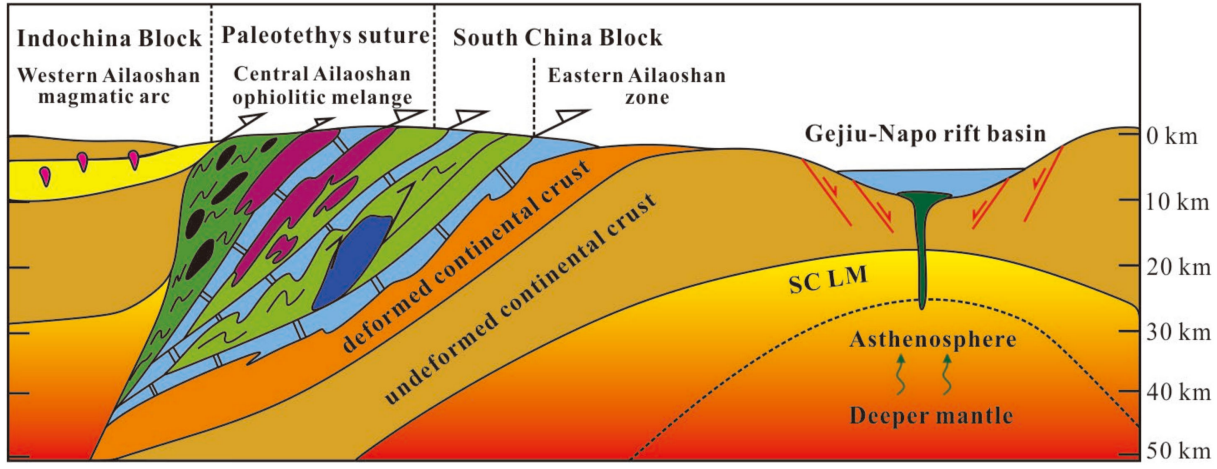

Figure 13. Schematic drawing of the tectonic evolution of the Gejiu-Napo rift event in Ailaoshan post-collisional setting (modified from [23]), SCLM: subcontinental lithospheric mantle.

\subsection{Relationship with the ELIP}

Traditionally, the GAAB were considered to be placed in the intermediate zone of the ELIP and most likely formed at the periphery of the ELIP with a low degree of melting of plume material $[7,20,34]$. Recent studies have suggested there was a post-ELIP magmatism in the period following $260 \mathrm{Ma}$ [20,82]. The Triassic basalts in the southern ELIP have mainly been found in the Kaiyun, Qilinshan, and Laochang-Kafang areas. Based on the methods of geochronology, geochemistry, and $\mathrm{Sr}-\mathrm{Nd}-\mathrm{Pb}$ isotope analyses, Shellnutt [82] thought the magmatism that formed in 252 to $242 \mathrm{Ma}$ in the spatial field of the ELIP was related to the post-ELIP magmatism caused by decompressive melting of the fossil Emeishan plume head beneath the South China crust that was associated with the collision between the South China and North China Blocks during the Middle Triassic. Zhang [20] concluded that, in Gejiu, these basalts were the product of the melting of the plume head after the main ELIP phase caused by the rift system along the southwestern margin of the South China Block during the Early Triassic. Zhang [16], on the other hand, thought there was no relationship between the GAAB and the ELIP because zircon U-Pb dating placed the age in Kafang at $214 \mathrm{Ma}$. It is noteworthy that the basalts in Kafang and Laochang both underwent intense alteration and metamorphism since their formation because of the extensive metallogenesis during the late Cretaceous tectonomagmatism, which may explain the inaccuracies in dating results.

Although the relationship between the GAAB and the ELIP has been discussed in recent publications [16,20], the GAAB, especially its eruption age, remain relatively understudied. Zhang [21] has reported the SIMS zircon U-Pb age of GAAB in Kafang was 244.4 Ma. The similar LA-ICP-MS $\mathrm{U}-\mathrm{Pb}$ age of Kaiyuan basalts in adjacent area was $247 \mathrm{Ma}$ [20]. In this study, the zircon U-Pb age reveals that the non-mineralized GAAB in Qilinshan were formed in 244 Ma. Generally, the zircon grains in basalts are small and dark in color. In addition, the existence of oscillatory zoning in zircon grains indicates their magmatic origin. The characteristics of trace elements show that the assimilation of crust in generation of the basalts was insignificant. Besides, the GAAB are interbedded within the Triassic Gejiu Formation, which was considered to be formed in 245 to 237 Ma [21]. Combining with the regional geology, the GAAB and the Gejiu Formation are the important constituents of the volcanic-sedimentary sequence in Middle Triassic in Gejiu area. Thus, we thought the zircon $\mathrm{U}-\mathrm{Pb}$ age can reflect the magmatic history of the GAAB.

After the formation of the ELIP in $\sim 260 \mathrm{Ma}$, minor magmatic events occurred around the center of ELIP between 252 to $242 \mathrm{Ma}$. However, these post-260 Ma magmatic events were not directly related to Emeishan magmatism. This is because most large igneous provinces worldwide had relatively short durations (1-5 Ma). ID-TIMS zircon $\mathrm{U}-\mathrm{Pb}$ ages show that the Karoo large igneous province in South Africa lasting about 1 Ma or less for the major pulse of magmatism [90,91]. The emplacement of large volumes of volcanic rocks during the main pulse of the Siberian Traps in Russia occurred within $<1 \mathrm{Ma}$ [92]. New CA-ID-TIMS U-Pb zircon ages from the Malwa Plateau indicate that the Deccan large igneous province in India erupted from 65.9 to $66.5 \mathrm{Ma}$ [93]. 
As discussed above, the geochemical characteristics of the GAAB are similar to the Emeishan high-Ti basalts. However, the U-Pb dating age of $244 \mathrm{Ma}$ obtained from Qilinshan basalts in Gejiu reveals a later date than the ELIP (ca. $260 \mathrm{Ma}$ ), as constrained by various dating methods in different kinds of rocks $[4,27,94]$. It is generally accepted that the magmatism in ELIP began at, and ended, shortly after $260 \mathrm{Ma}[4,8,82,95-97]$. Considering the age discrepancies and difference in tectonic setting, there is no geodynamic or genetic link between GAAB and ELIP. The similar geochemical characteristics between the GAAB and the Emeishan high-Ti basalts are most likely due to the similar magma source.

\section{Conclusions}

Combined with geochronological, petrological, and geochemical studies of the alkaline basalts in the Gejiu area, our conclusions are as follows:

1. Zircon $\mathrm{U}-\mathrm{Pb}$ dating results showed that the GAAB were formed in $244 \mathrm{Ma}$ (MSWD $=4.9, n=22$ ).

2. The GAAB, similar to OIB and Emeishan high-Ti basalts, displayed enriched LREE patterns, with LILEs enriched relative to HFSEs. The GAAB had consistent Sr-Nd isotope compositions: the $\left({ }^{87} \mathrm{Sr} /{ }^{86} \mathrm{Sr}\right)=0.7044-0.7048$, and $\varepsilon \mathrm{Nd}(\mathrm{t})=3.25-4.92$. The Pb isotopes were more complex, the $\left({ }^{206} \mathrm{~Pb} /{ }^{204} \mathrm{~Pb}\right) \mathrm{t}=17.493-18.197,\left({ }^{207} \mathrm{~Pb} /{ }^{204} \mathrm{~Pb}\right) \mathrm{t}=15.530-15.722$, $\left({ }^{208} \mathrm{~Pb} /{ }^{204} \mathrm{~Pb}\right) \mathrm{t}=37.713-38.853$, respectively.

3. The GAAB originated from deeper enriched mantle material with $5 \%$ to $15 \%$ partial melting of garnet lherzolite and a segregation depth between 2 and 4 GPa $(60-120 \mathrm{~km})$. During the formation of the GAAB, clinopyroxene and Ti-Fe oxides were fractionally crystallized with insignificant crustal contamination.

4. The GAAB were the product of the decompressive melting of the deeper enriched mantle in a extensional environment that was related to the Gejiu-Napo rift event formed in a post-collisional setting after the South China-Indochina coillision.

Supplementary Materials: The following is available online at http://www.mdpi.com/2075-163X/10/11/1030/s1, Table S1: Data of major and trace elements in this paper.

Author Contributions: Data curation, Z.S.; formal analysis, Z.S.; funding acquisition, Y.C.; investigation, Z.S.; project administration, Y.C.; supervision, Y.C.; writing-original draft, Z.S.; writing-review and editing, Y.C. All authors have read and agreed to the published version of the manuscript.

Funding: This research was funded by the National Natural Science Foundation of China (Grant No. 41972312, 41672329), the National Key Research and Development Project of China (Grant No. 2016YFC0600509), and the Project of China Geological Survey (Grant No. 1212011120341).

Acknowledgments: We are thankful to Guopei Mo, Zhenfei Ma, Lina Zhang, and Luxue Qin for their assistance with samples collection, Shibo Liu for his help with zircon U-Pb dating. We also thank Xiangguo Guo for his help with thin sections observation. We are also indebted to the academic editor and three anonymous reviewers for their critical and constructive comments which substantially improved an early version of the manuscript.

Conflicts of Interest: The authors declare no conflict of interest.

\section{References}

1. Condie, K.C. Secular variation in the composition of basalts, an index to mantle evolution. J. Petrol. 1985, 26, 545-563. [CrossRef]

2. Condie, K.C. Geochemical changes in basalts and andesites across the Archean-Proterozoic boundary: Identification and significance. Lithos 1989, 23, 1-18. [CrossRef]

3. Zhang, J.W.; Huang, Z.L.; Luo, T.Y.; Qian, Z.K.; Zhang, Y. Origin of early Triassic rift-related alkaline basalts from Southwest China: Age, isotope, and trace-element constraints. Int. Geol. Rev. 2013, 55, 1162-1178. [CrossRef]

4. Zhou, M.F.; Malpas, J.; Song, X.Y.; Robinson, P.T.; Sun, M.; Kennedy, A.K.; Lesher, C.M.; Keays, R.R. A temporal link between the Emeishan large igneous province (SW China) and the end-Guadalupian mass extinction. Earth Planet. Sci. Lett. 2002, 196, 113-122. [CrossRef] 
5. Zhou, M.F.; Robinson, P.T.; Lesher, C.M.; Keays, R.R.; Zhang, C.J.; Malpas, J. Geochemistry, petrogenesis, and metallogenesis of the Panzhihua gabbroic layered intrusion and associated Fe-Ti-V-oxide deposits, Sichuan Province, SW China. J. Petrol. 2005, 46, 2253-2280. [CrossRef]

6. Zhou, M.F.; Zhao, J.H.; Qi, L.; Su, W.; Hu, R.Z. Zircon U-Pb geochronology and elemental and Sr-Nd isotopic geochemistry of Permian mafic rocks in the Funing area, SW China. Contrib. Mineral. Petrol. 2006, 151, 1-19. [CrossRef]

7. Zhou, M.F.; Arndt, N.T.; Malpas, J.; Wang, C.Y.; Kennedy, A.K. Two magma series and associated ore deposit types in the Permian Emeishan large igneous province, SW China. Lithos 2008, 103, 352-368. [CrossRef]

8. Guo, F.; Fan, W.; Wang, Y.; Li, C. When did the Emeishan mantle plume activity start? Geochronological and geochemical evidence from ultramafic-mafic dikes in southwestern China. Int. Geol. Rev. 2004, 46, 226-234. [CrossRef]

9. Zhong, H.; Zhu, W.G. Geochronology of layered mafic intrusions from the Pan-Xi area in the Emeishan large igneous province, SW China. Miner. Depos. 2006, 41, 599-606. [CrossRef]

10. Wang, C.Y.; Zhou, M.F.; Keays, R.R. Geochemical constraints on the origin of the Permian Baimazhai mafic-ultramafic intrusion, SW China. Contrib. Mineral. Petrol. 2006, 152, 309-321. [CrossRef]

11. He, B.; Xu, Y.G.; Huang, X.; Luo, Z.; Shi, Y.; Yang, Q.; Yu, S. Age and duration of the Emeishan flood volcanism, SW China: Geochemistry and SHRIMP zircon U-Pb dating of silicic ignimbrites, post-volcanic Xuanwei Formation and clay tuff at the Chaotian section. Earth Planet. Sci. Lett. 2007, 255, 306-323. [CrossRef]

12. Shellnutt, J.G.; Zhou, M.F. Permian peralkaline, peraluminous and metaluminous A-type granites in the Panxi district, SW China: Their relationship to the Emeishan mantle plume. Chem. Geol. 2007, 243, $286-316$. [CrossRef]

13. Wang, X.K. The geological and geochemical characteristics of the basic volcanic rocks of Kafang deposit in Gejiu district. J. Kunming Univ. Sci. Technol. 1993, 18, 1-9. (In Chinese)

14. Zheng, S.H. An Analysis of the genesis of Cu deposit of Meta-Basic rock type Cu deposit of east Gejiu. Yunnan Geol. 2012, 31, 315-330. (In Chinese)

15. Zhang, X.L. Geochemical characteristics of basic volcanic rock in Indo-Chinese epoch in Gejiu, Yunnan, and its geotectonic background. Miner. Resour. Geol. 2011, 25, 429-435. (In Chinese)

16. Zhang, G.S.; Fang, W.X.; Peng, R.; Zheng, H.Y. Zircon U-Pb Chronology, Origin and Tectonic Significance of the Triassic High Potassic Volcanic Rock from Gejiu, Yunnan, Southwestern China. Geotecton. Metallog. 2019, 43, 1219-1235. (In Chinese)

17. Fang, W.X.; Jia, R.X. Characteristics of the Alkaline Picritic Volcanic Rocks in the Gejiu Superlarge Tin-Copper Deposit and their Continental Dynamic Implications. Geotecton. Metallog. 2011, 35, 137-148, (In Chinese with English Abstract).

18. Li, Y.S.; Qin, D.X.; Guo, N.N. Geotectonic setting and mineralization significance of indochina epoch basalt in eastern Gejiu of Yunnan. Nonferrous Met. 2009, 61, 104-109. (In Chinese)

19. Zhang, H.; Fang, W.X.; Du, Y.L. Geochemical Characteristics and Geological Significance of the Kafang Alkaline Volcanic Rocks in Gejiu Area, Yunnan Province. Geotecton. Metallog. 2014, 38, 885-897. (In Chinese)

20. Zhang, J.W.; Huang, Z.L.; Luo, T.Y.; Yan, Z.F. LA-ICP-MS zircon geochronology and platinum-group elements characteristics of the Triassic basalts, SW China: Implications for post-Emeishan large igneous province magmatism. J. Asian Earth Sci. 2014, 87, 69-78. [CrossRef]

21. Zhang, J.W.; Dai, C.G.; Huang, Z.L.; Luo, T.Y.; Qian, Z.K.; Zhang, Y. Age and petrogenesis of Anisian magnesian alkali basalts and their genetic association with the Kafang stratiform $\mathrm{Cu}$ deposit in the Gejiu supergiant tin-polymetallic district, SW China. Ore Geol. Rev. 2015, 69, 403-416. [CrossRef]

22. Cheng, Y.B.; Carl, S.; Mao, J.W. Granite, gabbro and mafic microgranular enclaves in the Gejiu area, Yunnan Province, China: A case of two-stage mixing of crust- and mantle-derived magmas. Contrib. Mineral. Petrol. 2012, 164, 659-676. [CrossRef]

23. Faure, M.; Lin, W.; Chu, Y.; Lepvrier, C. Triassic tectonics of the Ailaoshan Belt (SW China): Early Triassic collision between the South China and Indochina Blocks, and Middle Triassic intracontinental shearing. Tectonophysics 2016, 683, 27-42. [CrossRef]

24. Wang, X.; Metcalfe, I.; Jian, P.; He, L.; Wang, C. The Jinshajiang-Ailaoshan Suture Zone, China: Tectonostratigraphy, age and evolution. J. Asian Earth Sci. 2000, 18, 675-690. [CrossRef] 
25. Wang, Q.; Deng, J.; Li, C.; Li, G.; Yu, L.; Qiao, L. The boundary between the Simao and Yangtze blocks and their locations in Gondwana and Rodinia: Constraints from detrital and inherited zircons. Gondw. Res. 2014, 26, 438-448. [CrossRef]

26. Faure, M.; Nguyen, V.V.; Hoai, L.T.T.; Lepvrier, C. Early Paleozoic or Early-Middle Triassic collision between the South China and Indochina blocks: The controversy resolved? Structural insights from the Kon Tum massif (Central Vietnam). J. Asian Earth Sci. 2018, 166, 162-180. [CrossRef]

27. Xu, Y.G.; He, B.; Chung, S.L.; Menzies, M.A.; Frey, F.A. Geologic, geochemical, and geophysical consequences of plume involvement in the Emeishan flood-basalt province. Geology 2004, 32, 917-920. [CrossRef]

28. Liu, Y.S.; Gao, S.; Hu, Z.C.; Gao, C.G.; Zong, K.Q.; Wang, D.B. Continental and oceanic crust recycling-induced melt-peridotite interactions in the Trans-North China Orogen: U-Pb dating, Hf isotopes and trace elements in zircons from mantle xenoliths. J. Petrol. 2010, 51, 537-571. [CrossRef]

29. Ludwig, K.R. ISOPLOT 3.0: A Geochronological Toolkit for Microsoft Excel; Special Publication No. 4; Berkeley Geochronology Center: Berkeley, CA, USA, 2003; Volume 4, pp. 1-71.

30. Gao, S.; Liu, X.M.; Yuan, H.L.; Hattendorf, B.; Günther, D.; Chen, L.; Hu, S. Determination of Forty Two Major and Trace Elements in USGS and NIST SRM Glasses by Laser Ablation-Inductively Coupled Plasma-Mass Spectrometry. Geostand. Newsl. 2002, 26, 181-196. [CrossRef]

31. Yan, Q.R.; Wang, Z.Q.; Liu, S.W. Opening of the Tethys in southwest China and its significance to the breakup of East Gondwanaland in late Paleozoic: Evidence from SHRIMP U-Pb zircon analyses for the Garzê ophiolite block. Chin. Sci. Bull. 2005, 50, 256-264. [CrossRef]

32. Zhang, H.F.; Sun, M.; Zhou, X.H.; Fan, W.M.; Zhai, M.G.; Yin, J.F. Mesozoic lithosphere destruction beneath the North China craton: Evidence from major-, trace-element and $\mathrm{Sr}-\mathrm{Nd}-\mathrm{Pb}$ isotope studies of Fangcheng basalts. Contrib. Mineral. Petrol. 2002, 144, 241-253. [CrossRef]

33. Belshawet, N.S.; Freedman, P.A.; O'Nions, R.K.; Frank, M.; Guo, Y. A new variable dispersion double-focusing plasma mass spectrometer with performance illustrated for Pb isotopes. Int. J. Mass Spectrom. 1998, 181, 51-58. [CrossRef]

34. Xu, Y.G.; Chung, S.L.; Jahn, B.M.; Wu, G. Petrologic and geochemical constraints on the petrogenesis of Permian-Triassic Emeishan flood basalts in southwestern China. Lithos 2001, 58, 145-168. [CrossRef]

35. Sun, S.S.; McDonough, W.F. Chemical and isotopic systematics of oceanic basalts: Implications for mantle composition and processes. In Magmatism in the Ocean Basins; Geological Society London Special Publications: London, UK, 1989; pp. 313-345.

36. Yang, Z.X.; Mao, J.W.; Chen, M.H.; Cheng, Y.B.; Chang, Y. Geology, geochemistry and genesis of Kafang copper deposit in Gejiu, Yunnan Province. Acta Petrol. Sin. 2010, 26, 830-844, (In Chinese with English Abstract).

37. Zhang, Y.T.; Liu, J.Q.; Guo, Z.F. Permian basaltic rocks in the Tarim basin, NW China: Implications for plume-lithosphere interaction. Gondwana Res. 2010, 18, 596-610. [CrossRef]

38. Wang, Y.F.; Zhang, Z.C.; Wang, L.J.; Lv, L.S.; Li, H.B. Geochemical characteristics of Permian basalt from Hutiaoxia and Jin'an area of the Emeishan Large Igneous Province and constraints on their source region. Acta Petrol. Sin. 2013, 29, 4387-4403, (In Chinese with English Abstract).

39. Jung, S.; Hoernes, S. The major and trace element and isotope ( $\mathrm{Sr}, \mathrm{Nd}, \mathrm{O})$ geochemistry of Cenozoic alkaline rift-type volcanic rocks from the Rhon area (central Germany): Petrology, mantle source characteristics and implications for asthenosphere-lithosphere interactions. J. Volcanol. Geotherm. Res. 2000, 99, 27-53. [CrossRef]

40. Condie, K.C. Incompatible element ratios in oceanic basalts and komatiites, tracking deep mantle sources and continental growth rates with time. Geochem. Geophys. Geosyst. 2003, 4, 1005. [CrossRef]

41. Zhu, D.C.; Mo, X.X.; Wang, L.Q.; Zhao, Z.D.; Liao, Z.L. Hotspot-ridge interaction for the evolution of Neo-Tethys: Insights from the Late Jurassic-Early Cretaceous magmatism in southern Tibet. Acta Petrol. Sin. 2008, 24, 225-237. (In Chinese)

42. Fitton, J.G.; Saunders, A.D.; Norry, M.J.; Hardarson, B.S.; Talor, R.N. Thermal and chemical structure of the Iceland plume. Earth Planet. Sci. Lett. 1997, 153, 197-208. [CrossRef]

43. Staudigel, H.; Hart, S.R. Alteration of basaltic glass: Mechanisms and significance for the oceanic crust-seawater budget. Geochim. Cosmochim. Acta. 1983, 47, 337-350. [CrossRef] 
44. Wang, C.Y.; Zhou, M.F.; Qi, L. Permian flood basalts and magmatic intrusions in the Jinping (SW China)-Song $\mathrm{Da}$ (northern Vietnam) district: Mantle sources, crustal contamination and sulfide segregation. Chem. Geol. 2007, 243, 317-343. [CrossRef]

45. Zhang, B.L.; Lv, G.X.; Su, J.; Shen, X.L.; Liu, R.L.; Liu, J.G.; Hai, L.F.; Zhang, G.L. A study of the tectono-lithofacies mineralization regularities of the Gejiu tin polymetallic orefield, Yunnan, and prospecting in its western part. Earth Sci. Front. 2015, 22, 078-087. (In Chinese)

46. Zhao, J.H.; Zhou, M.F. Geochemistry of Neoproterozoic mafic intrusions in the Panzhihua district (Sichuan Province, SW China): Implications for subduction-related metasomatism in the upper mantle. Precambrian Res. 2007, 152, 27-47. [CrossRef]

47. Yang, G.X.; Li, Y.J.; Tong, L.L.; Li, G.Y.; Shen, R.; Li, Z.; Wu, L. Geochronology, geochemistry and petrogenesis of pillow basalts from Mayile region in West Junggar. Actor Petrol. Sin. 2016, 32, 522-536. (In Chinese)

48. Qi, L.; Zhou, M.F. Platinum-group elemental and Sr-Nd-Os isotopic geochemistry of Permian Emeishan flood basalts in Guizhou Province, SW China. Chem. Geol. 2008, 248, 83-103. [CrossRef]

49. Shaw, D.M. Trace element fractionation during anatexis. Geochim. Cosmochim. Acta 1970, 34, $237-243$. [CrossRef]

50. Saunders, A.D.; Storey, M.; Kent, R.W.; Norry, M.J. Consequences of plume-lithosphere interactions. In Magmatism and the Causes of Continental Break-up; Storey, B.C., Alabaster, T., Pankhurst, R.J., Eds.; Geological Society: London, UK, 1992; Volume 68, pp. 41-60.

51. Song, Y.; Frey, F.A.; Zhi, X. Isotopic characteristics of Hannuoba basalts, eastern China: Implications for their petrogenesis and the composition of subcontinental mantle. Chem. Geol. 1990, 85, 35-52. [CrossRef]

52. Basu, A.R.; Wang, J.W.; Huang, W.K.; Xie, G.H.; Tatsumoto, M. Major element, REE and Pb, Nd and Sr isotopic geochemistry of Cenozoic volcanic rocks of eastern China: Implication for their origin from suboceanic type mantle reservoirs. Earth Planet. Sci. Lett. 1991, 105, 149-169. [CrossRef]

53. Tatsumoto, M.; Nakamura, Y. DUPAL anomaly in the Sea of Japan: Lead, neodymium, and strontium isotopic variations at the eastern Eurasian continental margin. Geochim. Cosmochim. Acta 1991, 55, 3697-3708. [CrossRef]

54. Brenhin, K.; Blair, S. Plate tectonics and continental basaltic geochemistry throughout Earth history. Earth Planet. Sci. Lett. 2018, 481, 290-304.

55. Zhou, P.B.; Mukasa, S.B. Nd-Sr-Pb isotopic, and major and trace-element geochemistry of Cenozoic lavas from the Khorat Plateau, Thailand: Sources and petrogenesis. Chem. Geol. 1997, 137, 175-193. [CrossRef]

56. Jaques, A.L.; Green, D.H. Anhydrous melting of peridotite at $0-15 \mathrm{~kb}$ pressure and the genesis of tholeiitic basalts. Contrib. Mineral. Petrol. 1980, 73, 287-310. [CrossRef]

57. Takahashi, E.; Kushiro, I. Melting of a dry peridotite at high pressures and basalt magma genesis. Am. Miner. 1983, 68, 859-879.

58. Derakhshi, M.; Ghasemi, H.; Miao, L.C. Geochemistry and petrogenesis of Soltan Maidan basalts (E Alborz, Iran): Implications for asthenosphere-lithosphere interaction and rifting along the $\mathrm{N}$ margin of Gondwana. Geochemistry 2017, 77, 131-145. [CrossRef]

59. Herzberg, C. Depth and degree of melting of komatiites. J. Geophys. Res. 1992, 97, 4521-4540. [CrossRef]

60. Herzberg, C. Generation of plume magmas through time: An experimental perspective. Chem. Geol. 1995, 126, 1-16. [CrossRef]

61. DePaolo, D.J. Trace element and isotopic effects of combined wallrock assimilation and fractional crystallization. Earth Planet. Sci. Lett. 1981, 53, 189-202. [CrossRef]

62. Lemdjou, Y.B.; Zhang, D.; Jean, P.T.; Hu, J.X.; Nicaise, B.T.N.; Landry, S.T.; Yuan, Y. Elemental and Sr-Nd-Pb isotopic compositions, and $\mathrm{K}-\mathrm{Ar}$ ages of transitional and alkaline plateau basalts from the eastern edge of the West Cameroon Highlands (Cameroon Volcanic Line). Lithos 2020, 105-414. [CrossRef]

63. Hofmann, A.W.; Jochum, K.; Seufert, M.; White, W.M. Nb and Pb in oceanic basalts: New constraints on mantle evolution. Earth Planet. Sci. Lett. 1986, 79, 33-45. [CrossRef]

64. Hart, W.K.; WoldeGabriel, G.; Walter, R.C.; Mertzman, S.A. Basaltic volcanism in Ethiopia: Constraints on continental rifting and mantle interactions. J. Geophys. Res. Solid Earth 1989, 94, 7731-7748. [CrossRef]

65. Zhu, D.C.; Pan, G.T.; Mo, X.X.; Wang, L.Q.; Zhao, Z.D.; Liao, Z.L.; Geng, Q.R.; Dong, G.C. Identification for the Mesozoic OIB-type Basalts in Central Qinghai-Tibetan Plateau: Geochronology, Geochemistry and Their Tectonic Setting. Acta Geol. Sin. 2006, 80, 1312-1328, (In Chinese with English Abstract). 
66. Li, X.H.; Li, Z.X.; Zhou, H.W.; Liu, Y.; Kinny, P.D. U-Pb zircon geochronology, geochemistry and Nd isotopic study of Neoproterozoic bimodal volcanic rocks in the Kangdian Rift of South China: Implications for the initial rifting of Rodinia. Precambrian Res. 2002, 113, 135-154. [CrossRef]

67. Niu, Y.L. Some basic concepts and problems on the petrogenesis of intra-plate ocean island basalts. Chin. Sci. Bull. 2009, 54, 4148-4160. [CrossRef]

68. Hofmann, A.W. Mantle geochemistry: The message from oceanic volcanism. Nature 1997, 385, $219-229$. [CrossRef]

69. Maruyama, S.; Santosh, M.; Zhao, D. Superplume, supercontinent, and post-perovskite: Mantle dynamics and anti-plate tectonics on the core-mantle boundary. Gondwana Res. 2007, 11, 7-37. [CrossRef]

70. Davies, G.F. Mantle Convection for Geologists; Cambridge University Press: Cambridge, UK, 2011; p. 240.

71. Safonova, I.; Santosh, M. Accretionary complexes in the Asia-Pacific region: Tracing archives of ocean plate stratigraphy and tracking mantle plumes. Gondwana Res. 2014, 25, 126-158. [CrossRef]

72. Safonova, I.; Kojima, S.; Nakae, S.; Romer, R.L.; Seltmann, R.; Sano, H.; Onoue, T. Oceanic island basalts in accretionary complexes of SW Japan: Tectonic and petrogenetic implications. J. Asian Earth Sci. 2015, 113, 508-523. [CrossRef]

73. Fang, W.X.; Zhang, H.; Jia, R.X. Dynamics of Triassic Back-Arc Rift Basin and its Metallogenic Sequence in Gejiu of Yunnan Province to Napo of Guangxi Zhuang Autonomous Region, China. Geotecton. Metallog. 2011, 35, 552-566, (In Chinese with English Abstract).

74. Meschede, M. A method of discrimination between different types of mid-ocean ridge basalts and continental tholeiites with the Nb-Zr-Y diagram. Chem. Geol. 1986, 56, 207-218. [CrossRef]

75. Pearce, J.A.; Cann, J.R. Tectonic setting of basic volcanic rocks determined using trace element analyses. Earth Planet. Sci. Lett. 1973, 19, 290-300. [CrossRef]

76. Shellnutt, J.G.; Denyszyn, S.W.; Mundil, R. Precise age determination of mafic and felsic intrusive rocks from the Permian Emeishan large igneous province (SW China). Gondwana Res. 2012, 22, 118-126. [CrossRef]

77. Wood, D.A. The application of a Th-Hf-Ta diagram to problems of tectonomagmatic classification and to establishing the nature of crustal contamination of basaltic lavas of the British tertiary volcanic province. Earth Planet. Sci. Lett. 1980, 50, 11-30. [CrossRef]

78. Lai, C.K.; Meffre, S.; Crawford, A.J.; Zaw, K.; Xue, C.D.; Halpin, J.A. The Western Ailaoshan Volcanic Belts and their SE Asia connection: A new tectonic model for the Eastern Indochina Block. Gondwana Res. 2014, 26, 52-74. [CrossRef]

79. Liu, J.; Tran, M.D.; Tang, Y.; Nguyen, Q.L.; Tran, T.H.; Wu, W.; Chen, J.; Zhang, Z.; Zhao, Z. Permo-Triassic granitoids in the northern part of the Truong Son belt, NW Vietnam: Geochronology, geochemistry and tectonic implications. Gondwana Res. 2012, 22, 628-644. [CrossRef]

80. Lepvrier, C.; Maluski, H.; Tich, V.V.; Leyreloup, A.; Thi, P.T.; Nguyen, V.V. The Early Triassic Indosinian orogeny in Vietnam (Truong Son Belt and Kontum Massif); implications for the geodynamic evolution of Indochina. Tectonophysics 2004, 393, 87-118. [CrossRef]

81. Yan, D.P.; Zhou, M.F.; Wang, C.Y.; Xia, B. Structural and geochronological constraints on the tectonic evolution of the Dulong-Song Chay tectonic dome in Yunnan province, SW China. J. Asian Earth Sci. 2006, 28, 332-353. [CrossRef]

82. Shellnutt, J.G.; Zhou, M.F.; Yan, D.P.; Wang, Y. Longevity of the Permian Emeishan mantle plume (SW China): $1 \mathrm{Ma}, 8 \mathrm{Ma}$ or $18 \mathrm{Ma}$ ? Geol. Mag. 2008, 145, 373-388. [CrossRef]

83. Wang, Y.J.; Qian, X.; Cawood, P.A.; Liu, H.C.; Feng, Q.L.; Zhao, G.C.; Zhang, Y.H.; He, H.Y.; Zhang, P.Z. Closure of the East Paleotethyan Ocean and amalgamation of the Eastern Cimmerian and Southeast Asia continental fragment. Earth Sci. Rev. 2018, 186, 195-230. [CrossRef]

84. Lai, C.K.; Meffre, S.; Crawford, A.J.; Zaw, K.; Halpin, J.A.; Xue, C.D.; Salam, A. The Central Ailaoshan ophiolite and modern analogs. Gondwana Res. 2014, 26, 75-88. [CrossRef]

85. Zaw, K.; Meffre, S.; Lai, C.K.; Burrett, C.; Santosh, M.; Graham, I.; Ml, T.; Salam, A.; Kamvong, T.; Cromie, P. Tectonics and metallogeny of mainland Southeast Asia-A review and contribution. Gondwana Res. 2014, $26,5-30$.

86. Xu, J.; Xia, X.; Huang, C.; Cai, K.; Yin, C.; Lai, C.-K. Changes of provenance of Permian and Triassic sedimentary rocks from the Ailaoshan suture zone (SW China) with implications for the closure of the eastern Paleotethys. J. Asian Earth Sci. 2019, 170, 234-248. [CrossRef] 
87. Liu, C.; Deng, J.F.; Liu, J.L.; Shi, Y.L. Characteristics of volcanic rocks from Late Permian to Early Traissic in Ailaoshan tectonomagmatic belt and implications for tectonic settings. Acta Petrol. Sin. 2011, 27, 3590-3602, (in Chinese with English abstract).

88. Zi, J.W.; Cawood, P.A.; Fan, W.M.; Wang, Y.J.; Tohver, E.; McCuaig, T.C.; Peng, T.P. Triassic collision in the Paleo-Tethys Ocean constrained by volcanic activity in SW China. Lithos 2012, 144, 145-160. [CrossRef]

89. Roger, F.; Maluski, H.; Lepvrier, C.; Van, T.V.; Paquette, J.L. LA-ICPMS zircons U/Pb dating of Permo-Triassic and Cretaceous magmatisms in Northern Vietnam-geodynamical implications. J. Asian Earth Sci. 2012, 48, 72-82. [CrossRef]

90. Ivanov, A.V.; Meffre, S.; Thompson, J.; Corfu, F.; Vadim, S.; Kamenetsky, M.B.; Demonterova, E.I. Timing and genesis of the Karoo-Ferrar large igneous province: New high precision U-Pb data for Tasmania confirm short duration of the major magmatic pulse. Chem. Geol. 2017, 455, 32-43. [CrossRef]

91. Svensen, H.; Corfu, F.; Polteau, S.; Hammer, O.; Planke, S. Rapid magma emplacement in the Karoo Large Igneous Province. Earth Planet. Sci. Lett. 2012, 325-326, 1-9. [CrossRef]

92. Augland, L.E.; Ryabov, V.V.; Vernikovsky, V.A.; Planke, S.; Polozov, A.G.; Callegaro, S.; Jerram, D.A.; Svensen, H.H. The main pulse of the Siberian Traps expanded in size and composition. Sci. Rep. 2019, 18723. [CrossRef]

93. Michael, P.E.; Blair, S.; Kyle, M.S.; Gerta, K.; Thierry, A.; Syed, F.R.K. U-Pb zircon age constraints on the earliest eruptions of the Deccan Large Igneous Province, Malwa Plateau, India. Earth Planet. Sci. Lett. 2020, 540, 116249.

94. Shellnutt, J.G.; Jahn, B.M. Origin of late Permian Emeishan basaltic rocks from the Panxi region (SW China): Implications for the Ti-classification and spatial-compositional distribution of the Emeishan flood basalts. J. Volcanol. Geotherm. Res. 2011, 199, 85-95. [CrossRef]

95. Lo, C.H.; Chung, S.L.; Lee, T.Y.; Wu, G. Age of the Emeishan flood magmatism and relations to Permian-Triassic boundary events. Earth Planet. Sci. Lett. 2002, 198, 449-458. [CrossRef]

96. Boven, A.; Pasteels, P.; Punzalan, L.E.; Liu, J.; Luo, X.; Zhang, W.; Guo, Z.; Hertogen, J. ${ }^{40} \mathrm{Ar} /{ }^{39} \mathrm{Ar}$ geochronological constraints on the age and evolution of the Permo-Triassic Emeishan volcanic province, southwest China. J. Asian Earth Sci. 2002, 20, 157-175. [CrossRef]

97. Fan, W.; Wang, V.; Peng, T.; Miao, L.; Guo, F. Ar-Ar and U-Pb geochronology of late Paleozoic basalts in western Guangxi and its constraints on the eruption age of Emeishan basalt magmatism. Chin. Sci. Bull. 2004, 49, 2318-2327. (In Chinese) [CrossRef]

Publisher's Note: MDPI stays neutral with regard to jurisdictional claims in published maps and institutional affiliations.

(C) 2020 by the authors. Licensee MDPI, Basel, Switzerland. This article is an open access article distributed under the terms and conditions of the Creative Commons Attribution (CC BY) license (http://creativecommons.org/licenses/by/4.0/). 